INTER NATIONAL MONETARY FUND
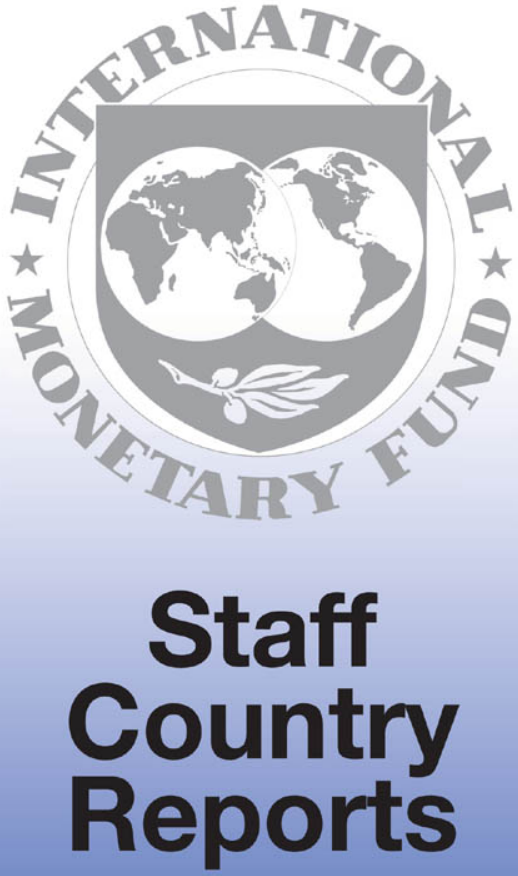
September 1999

IMF Staff Country Report No. 99/106

\section{The Bahamas: Selected Issues and Statistical Appendix}

This Selected Issues and Statistical Appendix report on The Bahamas was prepared by a staff team of the International Monetary Fund as background documentation for the periodic consultation with this member country. As such, the views expressed in this document are those of the staff team and do not necessarily reflect the views of the Government of The Bahamas or the Executive Board of the IMF.

Copies of this report are available to the public from

International Monetary Fund $\bullet$ Publication Services

700 19th Street, N.W. • Washington, D.C. 20431

Telephone: (202) 623-7430 - Telefax: (202) 623-7201

Telex (RCA): 248331 IMF UR

E-mail: publications@imf.org

Internet: http://www.imf.org

Price: $\$ 15.00$ a copy

\section{International Monetary Fund \\ Washington, D.C.}




\section{INTERNATIONAL MONETARY FUND}

\section{THE BAHAMAS \\ Selected Issues and Statistical Appendix}

Prepared by a staff team consisting of M. DaCosta (Head)

A. Gómez-Oliver, S. Itam, C. Piñerúa, and S. Shah

Approved by the Western Hemisphere Department

July 20, 1999

Contents

Basic Data. 3

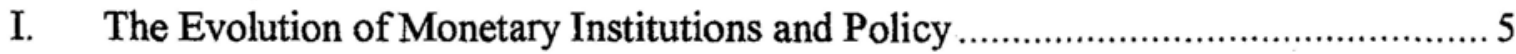

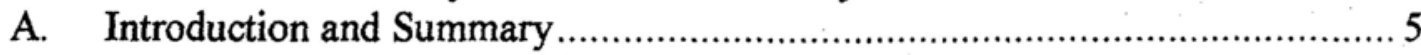

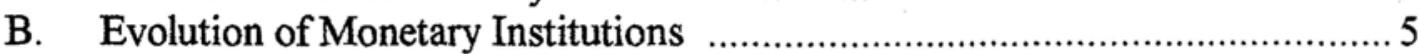

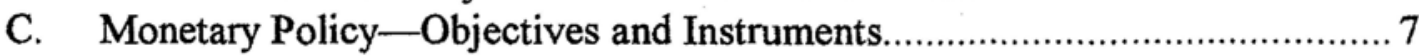

II. The Recent Widening of the External Current Account Deficit......................... 13

A. Introduction ................................................................................ 13

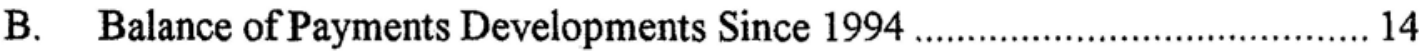

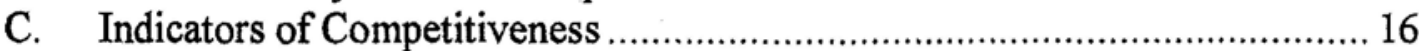

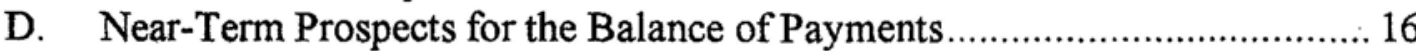

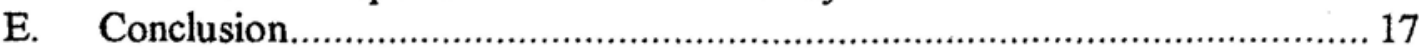

Figures

1. Ratio of Reserve Money to Foreign Assets .................................................. 18

$2 . \quad$ Comparative Deposit Rates ..................................................................... 19

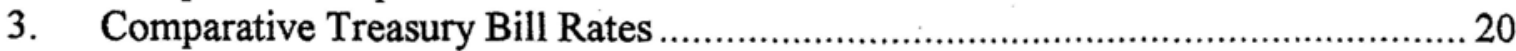

4. $\quad$ Summary Balance of Payments ....................................................................... 21

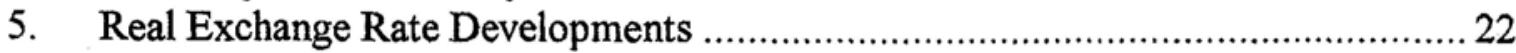

Boxes

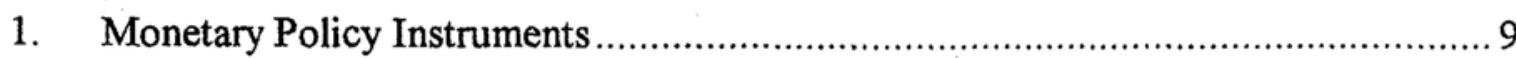

2 . Selected Monetary Policy and Operational Actions 1970-99 _........................ 11 
Statistical Appendix Tables

1. Geographic Distribution of Stopover Visitors ............................................ 23

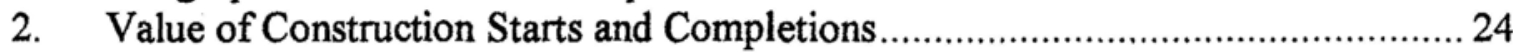

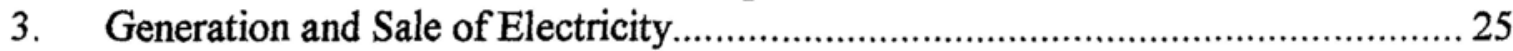

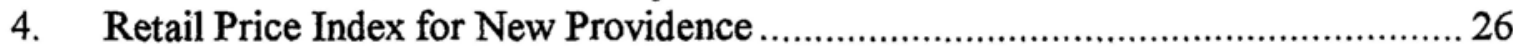

5 . Summary Operations of the Nonfinancial Public Sector .................................2 27

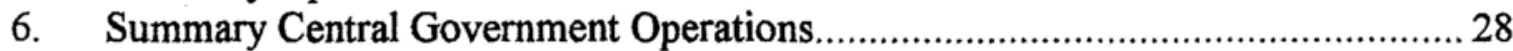

7. Central Government Revenue ............................................................... 29

8. Central Government Expenditure ................................................................. 31

9. Number of Employees in the Central Government ....................................... 33

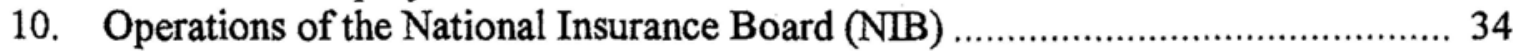

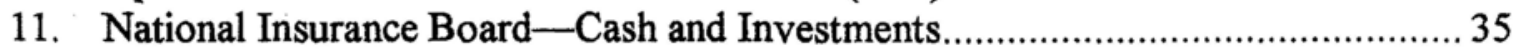

12. Consolidated Operations of Nonfinancial Public Corporations........................ 36

13. Operating Balances of Nonfinancial Public Corporations.................................. 37

14. Summary Accounts of the Financial System .............................................. 38

15. Accounts of the Central Bank ..................................................................... 40

16. Accounts of the Commercial Banks ...................................................... 42

17. Accounts of Other Local Financial Institutions ............................................ 43

18. Loans and Advances of Commercial Banks ...................................................44

19. Commercial Banks' Reserve Position ....................................................... 45

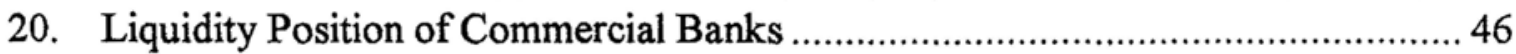

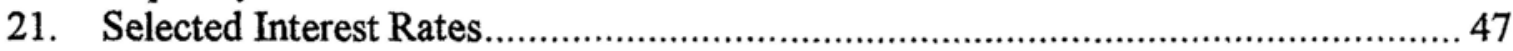

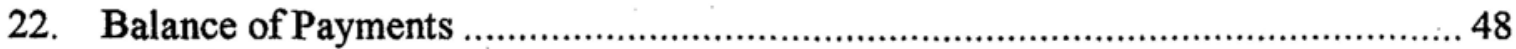

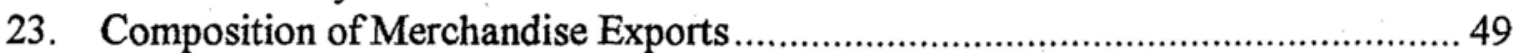

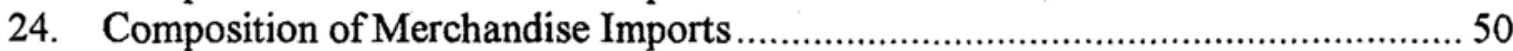

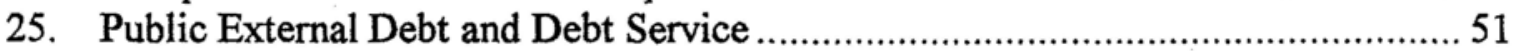

26. Comparative Real Exchange Rates ......................................................... 52 
The Bahamas: Basic Data

I. Social and Demographic Indicators

Area (sq. km)

Population (1998)

Total (thousand)

Rate of growth 1998 (percent)

Density (per sq. km.) (1998)

GDP per capita (US\$) (1998)

Population characteristics (1996)

Life expectancy at birth (years) (1996)

Crude birth rate (per thousand) (1996)

Crude death rate (per thousand) (1996)

Infant mortality (per thousand live births)
13,939

293.0

1.5

21.0

14,450

73.1

18.9

5.0

19.0

Nutrition (1992)

Calorie intake (per capita

a day)

Health (1993)

Population per physician

692

Population per hospital bed

Access to safe water

Percent of population (1992)

98.0

Education (1994)

Enrollment rates, in percent

Secondary education

86

Income distribution (1995)

Gini coefficient

0.4

II. Economic Indicators, 1994-98

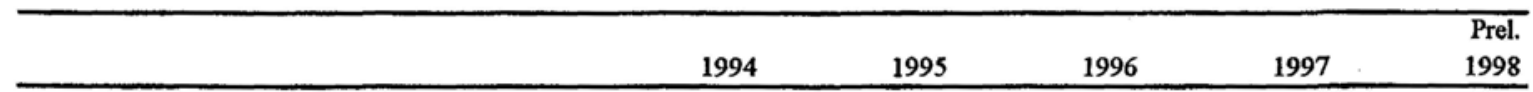

National accounts and prices

GDP at constant market pricess

(In annual percentage changes)

Consumer price index (average)

$\begin{array}{lllll}0.9 & 0.3 & 4.2 & 3.3 & 3.0 \\ 1.3 & 2.1 & 1.4 & 0.6 & 1.4\end{array}$

Central government finances

(In millions of Bahamian dollars)

Current Revenue

Noninterest expenditure

Primary balance (deficit -)

Overall balance (deficit -)

Memorandum items:

Primary balance (percent of GDP)

Overall balance (percent of GDP)

639

598

42

$-35$

1.3

$-1.0$

386

Money

Quasi-money

Net domestic assets

Credit to the public sector

Credit to the private sector
1,511

1,954

425

1,859
657

621

36

$-33$

1.3

$-0.9$

0.7

$-1.8$

$-1.0$

$-3.4$

0.4

402

416

485

1,720

1,891

2,489

2,090

2,245

392

2,264

2,551

2,060

2,819 


\section{The Bahamas: Basic Data}

II. Economic Indicators, 1994-98

\section{Balance of payments}

Trade balance

Exports, f.o.b.

Imports, f.o.b.

Services, income and transfers (net)

Of which

Interest on public debt

Current account

Capital account

Public

Private

Overall balance

Stock of net foreign assets of the central bank

Memorandum items:

Debt service ratio 1/

Current account (as percent of GDP)

External debt outstanding (as percent of GDP)

IMF data

Article VIII status

Intervention currency and rate

Quota

Fund holdings of local currency

Fund holdings as percent of quota Arrears with the Fund

(In millions of U.S. dollars)

$\begin{array}{rrrrr}-815 & -930 & -1,023 & -1,300 & -1,373 \\ 198 & 226 & 250 & 246 & 363 \\ -1,014 & -1,157 & -1,273 & -1,546 & -1,736 \\ 773 & 787 & 752 & 642 & 430 \\ & & & & \\ -7 & -8 & -17 & -13 & -6 \\ 42 & -143 & -271 & -658 & -943 \\ 57 & 89 & 157 & 403 & 724 \\ -20 & -29 & -25 & 23 & -11 \\ 77 & 118 & 182 & 380 & 735 \\ 9 & -3 & -8 & 57 & 119 \\ & & & & \\ 174 & 171 & 163 & 220 & 339 \\ & & & & \\ 3.9 & 3.8 & 3.4 & 5.0 & 3.5 \\ -1.2 & -4.2 & -7.2 & -16.7 & -22.5 \\ 9.8 & 8.8 & 7.8 & 9.9 & 8.3\end{array}$

Special Drawing Rights Department

Cumulative SDR allocation

Net acquisition or utilization $(-)$ of SDRs

Holdings of SDRs
As of 06/30/99

B 1.00 per U.S. dollar SDR 94.9 million SDR 88.7 million

93.4

None

SDR 10.23 million 10.22 million 0.01 million

1/ External debt service as percent of exports of goods and nonfactor services. 


\section{THE EVOLUTION OF MONETARY INSTITUTIONS AND POLICY}

\section{A. Introduction and Summary}

1. The purpose of this chapter is to summarize the evolution of monetary institutions and discuss the framework in which monetary policy is conducted in The Bahamas. Following a brief description of the evolution of institutions in Section B, the chapter summarizes the monetary policy objectives and constraints of the central ban, and assesses the instruments to achieve these objectives.

2. The main conclusion is that despite the limitations on monetary policy that derive from the fixed exchange rate peg with the U.S. dollar, the central bank has been able to use interest rate changes, selective credit controls, and moral suasion to achieve its monetary objectives. The effectiveness of these instruments has been enhanced by prudent fiscal policies, effective supervision of the financial system, and close monitoring of capital outflows.

\section{B. Evolution of Monetary Institutions}

3. Monetary management in the Bahamas was conducted under a currency board arrangement (The Commissioners of Currency) during the period 1919 to 1968 . The currency board issued the local currency, the Bahamas dollar (B\$), in exchange for pounds sterling at a fixed rate of $\mathrm{B} \$ 1$ to $£ 1$. As in the case of other currency boards, part of the rationale for the arrangement was to consolidate economic ties with the colonial power, the United Kingdom, and to ensure that the financing needs of the budget were not met through the unrestricted capacity of the government to issue currency.

4. During most of the currency board period economic activity was based on fishing and tourism, and economic cycles varied with the performance of these sectors. Moreover, periods of economic decline were aggravated by the currency board rule that required currency in circulation to be reduced in line with international reserves. Toward the latter part of the currency board period (the 1950s and the 1960s) several banks, trust companies, and investment firms began to establish operations in The Bahamas reflecting a number of factors, including:

- The postwar regime of exchange and investment controls, high tax rates, and the presence of a large amount of U.S. dollars in circulation in Europe; 
- $\quad$ measures by the U.S. government to restrict capital outflows in the face of a persistent balance of payments deficit; ${ }^{1}$ and

- the appeal of The Bahamas on account of its status as a tax haven, the ease with which companies could be established, bank secrecy legislation, the absence of exchange controls for nonresidents, proximity to the United States, and political stability.

5. By the mid-1960s more than 600 mostly small banks and financial firms had been established, and it became clear that the regulatory framework was inadequate to ensure certain minimum operational and prudential standards. This led to the introduction of the banks and Trust Companies Regulation Act of 1965 that laid down criteria for the licensing and supervision of banks, and for the withdrawal of licenses. By 1967 , enforcement of the provisions of the legislation led to a sharp contraction in the number of institutions to ninety, but it was becoming apparent that the institutional and legal framework of the currency board was not adequate to meet the needs of financial system supervision as well as of maintaining stability in monetary and credit conditions. The strains proved unsustainable in 1967, following the devaluation of sterling in that year. In light of the shift in the country's trading pattern in favor of the United States, and the increasing reliance of the Bahamian economy on the United States for tourism revenue and investment, in 1967 the government decided to switch the currency peg to the U.S. dollar at the rate of $\mathrm{B} \$ 1$ to US\$1. The devaluation of the Bahamian dollar led to large losses by domestic banks, and pointed to the weakness of an institutional framework that, inter alia, did not permit the currency board to act as a lender of last resort.

6. The replacement of the currency board system with The Bahamas monetary authority (BMA) in 1968, was aimed at addressing the weaknesses noted above. The BMA's main functions were to:

- Defend the local currency's peg to the U.S. dollar by centralizing and managing the country's foreign exchange holdings (except for transactions balances held by banks);

- $\quad$ provide domestic investment options to banks through auctions of government treasury bills;

\footnotetext{
${ }^{1}$ These measures included the interest equalization tax of 1963 which placed restrictions on the ability of U.S. banks to acquire non-U.S. paper; and Regulation Q, which imposed restrictions on the purchase of U.S. paper by non-U.S. residents.
} 
- develop the domestic payments mechanism through the introduction of a check clearing system; and

- $\quad$ supervise banks more closely.

7. While the BMA's responsibilities widened relative to those of the currency board, its overriding objectives remained that of defending the exchange rate by maintaining an adequate ratio of international reserves to currency issue. This central task led to a broadly restrictive policy stance, which - as in the case of the currency board-resulted in a tendency to limit the growth in currency issue even in periods of slow economic activity. ${ }^{2}$ Moreover, the BMA lacked the instruments needed to control domestic liquidity and credit, as evidenced by its inability to contain the growth of liquidity and bank credit caused by the banks' caused by the banks' liquidation of their sterling-denominated assets following the devaluation of sterling and the Bahamian dollar in 1967.

8. To address the need for strengthened monetary instruments, the Central Bank of the Bahamas (CBB) was established in 1974 with a broad mandate of not only preserving the exchange rate peg to the U.S. dollar, but also performing an enhanced role as banker and lender to the government and banks, administrator of the exchange control regime, controller of domestic liquidity and credit, and supervisor of the financial system. The broader powers conferred by the central bank legislation permitted greater (and more frequent) use of available instruments, particularly the interest rate, selective/prudential credit controls, and moral suasion. Also, the enhanced role and powers permitted greater flexibility in adhering to the operational rule relating to the international reserve cover for base money (Figure 1).

\section{Monetary Policy-Objectives and Instruments}

9. The main objective of the monetary policy in The Bahamas is to promote credit and balance of payments conditions that preserve the longstanding parity between the Bahamian dollar and the U.S. dollar. Meeting this goal requires the central bank to keep the supply of reserve money in line with international reserves. ${ }^{3}$ For these purposes, the CBB monitors the key aggregates underlying liquidity growth, including credit extended by the

\footnotetext{
${ }^{2}$ In mid-1971, for example, in the midst of an economic downturn, the volume of currency issue had contracted by about 25 percent, compared with the level at end-1969. This action helped raise the international reserve cover of the currency from 70 percent to 100 percent.

${ }^{3}$ The Central Bank Act (1974) stipulates that the external assets of the central bank shall at no time be less than 50 percent of the sum of currency in circulation and demand liabilities of the central bank.
} 
financial system and reserve money, and stands ready to take corrective measures if it determines that developments in these aggregates could create pressure on the exchange rate or result in unsustainable losses of international reserves.

10. The main instruments of monetary policy available to the CBB include the bank (discount) rate, selective/prudential credit controls, and moral suasion, supplemented by capital controls. Changes in reserve requirements have not been used since the establishment of the central bank, and the CBB markets treasury bills and government bonds on behalf of the government, but the use of these instruments for open market operations has been limited (Box 1).

\section{The discount rate}

11. Banks do not normally borrow resources from the CBB, except in emergencies, therefore, the direct use of this instrument to influence banks' behavior is limited. ${ }^{4}$ Rather, the scope for affecting domestic interest rates and economic activity through changes in the discount rate stems from the close link between that rate and the commercial banks' prime rate. $^{5}$ The discount rate was changed frequently in the 1980s and early 1990 s reflecting the central bank's efforts to influence the banks' lending behavior. However, between 1994 and 1998 , for example, the banks' excess liquidity ${ }^{6}$ increased steadily, reaching the equivalent of one quarter of required liquid assets by the end of the year. The lack of flexibility in the discount rate appears to have reflected, in part, the authorities' desire to avoid frequent changes in mortgage rates, which are invariably tied to the prime rate. Following continued growth in liquidity during the first half of 1999 , the discount rate was lowered from 6.5 percent to 5.75 percent at end-June. This actions was followed by a decline in the prime rate from 6.75 percent to 6 percent.

\footnotetext{
${ }^{4}$ The most recent occasion when the banks borrowed a significant amount (B \$21 million) from the CBB was in 1988 when the country faced an acute liquidity and payments crisis. The loan was repaid in 1996. The CBB lent B $\$ 0.8$ million in September 1997 to a bank which became insolvent and was closed.

${ }^{5}$ The prime rate is the reference rate to which loans to government, prime corporate customers, and for mortgages are linked. In principle, the CBB and commercial banks jointly determine the prime rate, but a decision to change the rate is not normally taken without the agreement of the CBB. The CBB consults the ministry of finance before making a recommendation regarding a change in the prime rate.
}

${ }^{6}$ Defined as liquid assets less minimum required liquid assets. The latter is equivalent to 20 percent of banks' demand deposits, and 15 percent of time and saving deposits. 


\section{Box 1. The Bahamas: Monetary Policy Instruments}

\begin{tabular}{|c|c|c|}
\hline Description & Objectives & Recent use \\
\hline $\begin{array}{l}\text { 1. Central bank discount rate } \\
\text { Rate applies to borrowing by banks and } \\
\text { nonbank financial institutions from the central } \\
\text { bank. }\end{array}$ & $\begin{array}{l}\text { Changes in the discount rate affect market interest } \\
\text { rates, since the commercial banks' prime rate is tied } \\
\text { to it. Also, changes in this rate are used to signal the } \\
\text { central bank's view of the liquidity situation in the } \\
\text { banking system, thereby influencing banks' } \\
\text { behavior. }\end{array}$ & $\begin{array}{l}\text { Gradually reduced from } 9 \text { percent in } \\
1991 \text { to } 6.5 \text { percent in } 1994 \text {, with } \\
\text { corresponding adjustments in the } \\
\text { prime rate (which was reduced from } \\
9 \text { percent to } 6.75 \text { percent over the } \\
\text { same period). The rate was reduced } \\
\text { further to } 5.75 \text { percent in June } 1999 \text {. }\end{array}$ \\
\hline $\begin{array}{l}\text { 2. Reserve requirements } \\
\text { The reserve requirements, calculated against } \\
\text { commercial banks' deposit liabilities, apply in } \\
\text { two tranches-statutory reserves and liquid } \\
\text { asset ratio (LAR). Statutory reserves comprise } \\
\text { vault cash and banks' deposits with the central } \\
\text { bank. In addition to statutory reserves, the } \\
\text { eligible assets for LAR are the treasury bills } \\
\text { and government bonds, bonds issued by the } \\
\text { Bahamas Mortgage Corporation, and } \\
\text { commercial bank loans for low-income } \\
\text { housing development; the latter two are } \\
\text { government-guaranteed obligations. Penalties } \\
\text { are assessed if actual reserve holdings fall } \\
\text { below requirement.1/ }\end{array}$ & $\begin{array}{l}\text { Changes in reserve requirements, affect the liquidity } \\
\text { position of commercial banks and their ability to } \\
\text { extend credit. The CBB may increase the statutory } \\
\text { reserve requirement up to } 20 \text { percent, and the LAR } \\
\text { to } 25 \text { percent, of banks' deposit liabilities. The } \\
\text { reserve requirements also serve as a prudential } \\
\text { objective, as a back-up for the banks' deposit } \\
\text { liabilities. }\end{array}$ & $\begin{array}{l}\text { Reserve requirements have not been } \\
\text { changed since they were instituted in } \\
1974 \text { and remain fixed at } 5 \text { percent } \\
\text { for statutory reserves and, for LAR, } \\
\text { at } 15 \text { percent for demand deposit, } \\
\text { and } 20 \text { percent for savings and fixed } \\
\text { deposits. }\end{array}$ \\
\hline $\begin{array}{l}\text { 3. Open-market operations } \\
\text { Central bank buys and selis government } \\
\text { securities to banks and nonbank institutions. }\end{array}$ & $\begin{array}{l}\text { Objective is to add or reduce liquidity in the } \\
\text { financial system (and the economy as a whole) } \\
\text { thereby influencing the ability of financial } \\
\text { institutions to provide credit to the private sector. }\end{array}$ & $\begin{array}{l}\text { Most purchases of and sales of } \\
\text { treasury bills are carried out in line } \\
\text { with government financing } \\
\text { objectives. The CBB does not make } \\
\text { use of open-market operations for } \\
\text { liquidity management purposes, } \\
\text { except to smooth out seasonal } \\
\text { variations. Government foreign bond } \\
\text { issue of US\$50 million in early } 1977 \\
\text { and domestic bond issue of } B \$ 28 \\
\text { million in April } 1999 \text { reflected } \\
\text { domestic liquidity considerations. }\end{array}$ \\
\hline $\begin{array}{l}\text { 4. Capital controls } \\
\text { All outward capital transfers by residents, } \\
\text { including purchases of securities and direct } \\
\text { investment, require authorization by central } \\
\text { bank.2/. }\end{array}$ & $\begin{array}{l}\text { Used to avoid large and uncontrolled large capital } \\
\text { movements that could affect the balance of } \\
\text { payments and deplete international reserves. }\end{array}$ & $\begin{array}{l}\text { Capital controls have been } \\
\text { maintained at their current level for } \\
\text { several years. }\end{array}$ \\
\hline $\begin{array}{l}\text { 5. Selective/prudential controls and moral } \\
\text { suasion } \\
\text { Used to restrict growth in consumer credit, the } \\
\text { largest component of commercial bank loans to } \\
\text { private sector. }\end{array}$ & $\begin{array}{l}\text { Controls have been applied through use of margin } \\
\text { and collateral requirements on installment loans. In } \\
\text { addition, moral suasion is used to indicate to banks } \\
\text { that they should restrict credit. }\end{array}$ & $\begin{array}{l}\text { CBB has made frequent use of this } \\
\text { instrument. In } 1990 \text {, it required } \\
\text { banks to raise minimum collateral } \\
\text { amounts against consumer loans } \\
\text { from } 25 \text { percent to } 35 \text { percent. In } \\
1995 \text {, it asked banks to voluntarily } \\
\text { curtail lending, specifically for } \\
\text { consumption purposes. In May } 1998 \text {, } \\
\text { CBB requested banks to require } \\
\text { collateral and higher down payments } \\
\text { against consumer loans and, } \\
\text { generally, to exercise restraint in } \\
\text { extending such loans. }\end{array}$ \\
\hline $\begin{array}{l}\text { 6. Other instruments } \\
\text { Shifts in public sector bank deposits among } \\
\text { commercial banks. }\end{array}$ & $\begin{array}{l}\text { Amounts and timing of the shifts can be managed to } \\
\text { affect the banks' liquidity position. }\end{array}$ & $\begin{array}{l}\text { CBB used the placement of the social } \\
\text { security system's deposits as a } \\
\text { monetary policy instrument in the } \\
\text { late } 1980 \text { s. }\end{array}$ \\
\hline
\end{tabular}

1/ Current laws authorize the CBB to assess penalty for the nonobservance of reserve requirements at one tenth of one of the shortage amount calculated on a daily basis. However, the maximum penalty rate cannot exceed twice the bank rate.

2/Open position in domestic currency assets and liabilities is limited to $\mathrm{B} \$ 500,000$ either way, which requires commercial banks to sell or buy foreign exchange to or from the central bank if actual holdings exceed or fall short of this limit. The open position is calculated on a daily basis and exceptions are generally not granted. 
12. Changes in commercial bank interest triggered by movements in the discount rate affect a significant proportion of borrowers, including large businesses and mortgage holders, and combined with credit controls and moral suasion, have been broadly successful in achieving the central bank's monetary objectives. Despite the Bahamas' proximity to the United States and the exchange rate peg, the small interest rate differentials between the two countries (see Figures 2 and 3 ) have not resulted in capital flows partly on account of exchange control regulations. These controls, the clear separation of offshore from domestic banking, the ample supply of Bahamian dollar funds, and the confidence in the government's policies in recent years to maintain the exchange rate peg appear to have acted to limit the capacity and demand of commercial banks and residents to borrow U.S. dollars for domestic projects, or to seek ways of shifting from local currency deposits/assets into U.S. dollar deposits. $^{7}$

\section{Selective/prudential controls over private sector credit and moral suasion}

\section{Selective credit controls and prudential measures to influence the growth in} credit comprise mainly central bank variations in the minimum collateral or down payment required from borrowers seeking to qualify for a consumer loan $(\operatorname{Box} 2)^{8}$. This instrument has been aimed mainly as slowing down the rate of growth of consumer credit thereby easing pressure on international reserves. On some occasions, an easing of collateral requirements has been used to help stimulate credit growth to the private sector.

14. Moral suasion in The Bahamas takes the form of circulars from the central bank to commercial banks indicating the former's concern about the growth in private sector credit (or consumer credit in particular), and recommending that banks reduce the rate of credit expansion over the coming months. The most recent use of this instrument occurred in May 1998 when the CBB indicated to the banks that from March 1997 to March 1998 private sector credit had increased by 14 percent, while consumer credit increased by 26.7 percent. The bank noted that such rates of growth were unsustainable, and asked banks to exercise restraint. The measure proved effective in slowing down credit growth. By end-1998, the rate of growth in consumer lending had declined to 14.7 percent, and in total private sector credit to 11.1 percent, from the levels at end-1997.

\footnotetext{
${ }^{7}$ Residents' U.S. dollar-denominated deposits account for about 2 percent of total bank deposits.
}

${ }^{8}$ In recent years, consumer credit has been the fastest growing component of total private sector credit, increasing from 31 percent of total loans in 1995 to 40 percent in 1998. 
Box 2. The Bahamas: Selected Monetary Policy and Operational Actions 1970-99

I. $\quad \mathbf{1 9 7 0 - 8 0}$

- $\quad$ Clearing arrangements established to facilitate payments system (1971)

Prime rate increased from 8.5 percent to 9 percent (1972) and 9.5 percent (1974)

Bahamian dollar devalued in line with the U.S. dollar (February 1973)

Central bank established (1974)

Prime rate lowered to 9 percent (1979)

Central bank discount rate raised from 0.5 percent above prime, to 1 percent (1979)

Prime rate raised to 11 percent (1980)

Interest rate ceilings on commercial bank loans eliminated (1980)

Discount rate raised to 13 percent, margin over prime raised to 2 percent (1980)

II. 1981-85

- $\quad$ Discount rate margin eliminated (1981)

Central bank placement of deposits at selected commercial banks to ease liquidity pressures (1981)

Reinstatement of 2 percent margin over prime rate as the central bank discount rate (1982)

Placement by central bank of National Insurance Board deposits with selected commercial banks to ease liquidity pressures (1982)

Discount rate lowered from 10 percent to 9 percent (1983)

Discount rate raised to 9.5 percent (1984)

Discount rate lowered to 8.5 percent (1985)

III. 1986-90

- $\quad$ Discount rate lowered to 7.5 percent (1986)

- $\quad$ Discount rate raised to 9 percent (1988)

- Interest rate ceiling of 8 percent set on new bank deposits to halt destabilizing shifts of deposits among banks (1988)

Central bank tightened prudential guidelines on consumer loans by requiring borrowers to contribute a minimum equity (downpayment) of 35 percent of the value of the asset being acquired (1988)

Special issue of government bonds made to help slow the growth of consumer credit (1990)

IV. 1991-95

- $\quad$ Discount rate lowered from 9 percent to 7.5 percent (1992)

- $\quad$ Ceiling on deposit rate lowered to 7 percent (1992)

- $\quad$ Equity requirement of 35 percent for consumer loans removed (1993)

- $\quad$ Prime rate reduced to 7.75 percent, and ceiling on deposit rate lowered to 6.75 percent (1993)

- Discount rate lowered to 7 percent and ceiling on deposit rate lowered to 6.25 percent (1993)

- $\quad$ Prime rate reduced to 7.25 percent (1993)

- $\quad$ Discount rate reduced to 6.5 percent (1994)

- $\quad$ Ceiling on deposit rates eliminated (1994)

- Letter to banks issued requesting restraint on credit to the private sector (1995)

V. 1996-99

- $\quad$ Prudential guidelines on consumer credit tightened starting in May 1998.

- $\quad$ Discount rate reduced to 5.75 percent in June 1999 


\section{Open market operations}

\section{Open market operations-the purchase and sale of government or central bank} paper at market interest rates aimed at affecting bank's liquidity-are not used frequently. According to current practice, the CBB, acting as agent for the government, periodically conducts treasury bill auctions on occasions and in amounts which reflect, for the most part, the government's funding requirements. For each issue, a "cut-off" interest rate is set (i.e., the maximum interest rate that will be paid on the treasury bills issued). At times this rate ( 3 percent in the most recent auctions) has been considered too low by participants, and a number of issues have not been fully subscribed initially. When this occurs, the unsold bills are absorbed by the central bank and form a pool of interest-bearing assets that are available to banks to meet their liquid assets requirement. Reflecting the banks' excess liquidity for most of 1998 the CBB's holdings of treasury bills declined rapidly in early 1998 and were close to zero for most of the year. ${ }^{9}$

16. The CBB also sells on behalf of the government bonds ranging in maturity from 5 to 20 years, the yield on which is fixed at a premium (currently 0.5 percentage point) over the prime rate. ${ }^{10}$ Unlike treasury bills, bonds are not auctioned but "placed" with selected groups of buyers. Of the B $\$ 1,185$ million in total bonds outstanding at end-1998, only B $\$ 226$ million (22 percent) was held by commercial banks. The central bank, in consultation with the ministry of finance, is exploring options for future sales/placements of government bonds, including through auctions.

17. While, as noted, most of the purchases and sales of government paper have been carried out in line with government financing requirements, collaboration between the central bank and the treasury also allows some scope for monetary policy considerations, for example, in the timing of new issues. Moreover, the use of government paper specifically for monetary purposes is not unprecedented. In 1990, a special issue of government bonds was aimed at slowing the growth of consumer credit. Nevertheless, open market operations are unlikely to develop fully into an effective policy instrument in the

\footnotetext{
${ }^{9}$ The amount of the outstanding treasury bills is limited by law to 25 percent of the government's average ordinary revenues in the three preceding years. At end-June 1999 the amount of outstanding treasury bills was $\mathrm{B} \$ 132.5$ million, of which about $\mathrm{B} \$ 30$ million is rolled over each quarter, compared with $\$ 103.4$ million in banks' excess reserves.

${ }^{10}$ The premium had been as high as 1.25 percent in recent periods beginning in 1996, but, in line with a declining trend in domestic interest rates since then, the premium was reduced to 0.5 percent or lower in most recent periods.
} 
absence of a secondary market in government paper. ${ }^{11}$ It is expected that the forthcoming stock market would help facilitate the development of such a market.

\section{Conclusion}

18. The evolution of monetary institutions has been accompanied by an increased menu of monetary policy instruments in The Bahamas. While the main objective of policy remains that of preserving the fixed exchange rate peg to the U.S. dollar, the central bank has been able to affect banks' behavior through a combination of interest rate changes, selective and prudential credit controls, moral suasion, and to a limited extent-open market operations. Maintaining an adequate level of international reserves-the key operational goal of the authorities - has been facilitated by sound fiscal policies and effective bank supervision, while existing capital controls appear to have helped smooth out capital flows without restricting investment and economic activity. The current framework appears to have worked well, but the challenge for monetary policy in future will be how to ensure continued effectiveness of policy instruments in the context of the growing sophistication of financial markets and institutions. As institutions develop and proliferate, reliance on instruments such as moral suasion is likely to decline, and increased scope will have to be sought for other tools such as market-based purchases and sales of government paper for liquidity management.

\section{The Recent Widening of THE EXTERnal CuRRENT ACCOUNT DEFICIT}

\section{A. Introduction}

19. This chapter reviews the main factors behind the widening of the external current account of The Bahamas and its financing during the period 1994 to 1998. In light of this review, an assessment of the country's competitiveness, and estimates of the balance of payments for 1999 , the chapter concludes that the current account widening does not reflect a serious problem of external imbalance. Instead, it stemmed largely from a temporary, sharp rise in imports of goods and services associated with investment projects in the tourism, shipping, and construction sectors that resulted from the government's policies to raise incomes and reduce unemployment by attracting foreign investors.

\footnotetext{
${ }^{11}$ At present, treasury bills and bonds remain with the buyer until maturity or may be sold back to the central bank before maturity at little or no penalty.
} 


\section{B. Balance of Payments Developments Since 1994}

20. The external current account deficit of The Bahamas widened from 3 percent of GDP in 1994 to 22 percent of GDP in 1998 (Figure 4). The deterioration was due largely to (i) a sharp increase in imports of goods and services associated with investment projects in the tourism sector (comprising mainly the refurbishing and expansion of existing hotels); (ii) imports related to the pickup in investment in other sectors, particularly shipping and residential construction; and (iii) a slowdown in the growth of tourist arrivals associated with the construction work. Reflecting these factors, the value of capital and manufactured goods imports rose by a total of about 12 percentage points of GDP between 1994 and 1998, tourist receipts declined by 5 percentage points, and other net service payments rose by about 6 percentage points of GDP.

21. The increase in imports related to investment projects in tourism and other sectors stemmed from the authorities' policies to attract private investment through tax incentives, the privatization of state-owned hotels, and the upgrading of supporting infrastructure such as roads, airports, water supply, telecommunications, and electricity. These policies, supported by a pickup in consumer demand in the United States (the main tourism market) and the government's public commitment to sound fiscal management helped increase confidence and stimulate considerable interest on the part of foreign investors.

\section{The main projects in tourism, shipping, and construction over the period}

1994-98 included (i) the Phase I refurbishing of the country's largest resort during 1995-96 (at a cost of about US $\$ 250$ million), that was accompanied by the extensive refurbishing and expansion of other properties; (ii) the construction of a new ship repair and transshipment facility on Grand Bahama in 1996 (at a cost of US\$90 million); (iii) investment by cruise lines of about US $\$ 45$ million in the development of dedicated ports of call; (iv) the Phase II expansion of the Atlantis Resort during 1997-98 at a cost of about US\$400-500 million; ${ }^{12}$ (v) the ongoing development of a large tourist resort on Grand Bahama; and (vi) the construction of several residential and commercial properties. The increase in the demand for imports linked to these projects was the main factor behind the expansion in total merchandise imports from 30 percent of GDP in 1994 to 41 percent in 1998. Imports of capital and manufactured goods rose by a combined 12 percentage points of GDP, with the latter comprising mainly supplies for the tourist resorts. ${ }^{13}$

\footnotetext{
${ }^{12}$ Following its completion in late 1998, this project resulted in an increase in the number of available rooms in New Providence (the main tourism center) by 1,200 , or 17.6 percent.

${ }^{13}$ Information on the increase in imports of consumer goods associated with the marked growth in consumer credit is not available, but estimates point to an increase of no more than about 2 percentage points of GDP.
} 
23. Developments in the services account also contributed to the widening of the current account deficit. The surplus of the service balance declined from 26 percent of GDP in 1994-96 to 14 percent of GDP in 1998, owing mainly to the increase in imports of construction services (originating in the tourism and shipping projects) as well as a decline in travel receipts due to the temporary reduction in hotel capacity also associated with the construction work.

24. The current account deficits in 1997-98 were financed largely by equity investments, reinvested earnings, and loans from the private sector. Almost 40 percent of total inflows of identified direct investment (equivalent to 4 percent of GDP) in 1998 were directed to the Atlantis resort project; with the remainder channeled to other tourism projects and purchases of real estate. Bank loans and other private capital also helped finance the tourism and other projects. ${ }^{14}$ By contrast, public sector net capital inflows were negative for most of the 1994-98 period reflecting an improvement in fiscal performance, and the public external debt outstanding fell from 10 percent of GDP in 1994 to about 8.3 percent of GDP in 1998.

25. An important aspect of recent balance of payments developments also is that despite the widening of the current account deficit, the international reserve position of the central bank strengthened from the equivalent of nine weeks of imports (78 percent of base money) at end-1994 to almost eleven weeks of imports (114 percent of base money) at end-1998. This improvement reflected mainly a restrained fiscal policy stance and efforts to contain private sector credit growth.

\section{Indicators of Competitiveness}

26. While there was a small appreciation ( 5 percent) in the real effective exchange rate (REER) index of The Bahamas since 1995 (Figure 5 and Statistical Appendix Table 26); ${ }^{15}$ other indicators point to the country's ability to maintain its competitiveness based on:

${ }^{14}$ Information on the financing of the current account is incomplete (as evidenced by the large value for errors and omissions). The authorities have initiated efforts to help identify the nature of these inflows.

${ }^{15}$ It has been pointed out that the real exchange rate calculated using consumer prices may not be an appropriate measure of international competitiveness when changes in relative prices are explained by productivity differentials between the home country and the trading 
- A moderate growth in costs throughout the economy in recent years, evidenced by wage increases in most sectors of the economy averaging about 3-4 percent a year; ${ }^{16}$

- the ability of the hotel sector to raise room rates since 1995 at a faster pace than that of wages, while at the same time achieving occupancy rates much higher than those in the rest of the Caribbean region. These factors helped contribute to an improvement in hotel profitability (as evidenced partly by the marked increase over the past two years in the share price of the company that controls the country's largest tourist resort);

- some indications of an increase in productivity in tourism based on the recent efforts to enhance training; and

- $\quad$ continued strong demand for The Bahamas as a location for banking and trust operations, and for investments in residential property.

\section{Near-Term Prospects for the Balance of Payments}

27. Indications are that the external current account will begin to narrow in 1999 based on the following factors:

- A projected sharp improvement in tourism revenue owing to the marked increase in hotel capacity, hotel occupancy, room prices, and advance bookings following the completion of the large hotel projects. Receipts from visitors increased more than 40 percent in the first quarter of 1999 with respect to the same period a year earlier, and on this basis some estimates point to an improvement in the services balance of the current account by about 4 percentage points of GDP for the year as a whole;

- A tapering off in imports of goods and services associated with the hotel construction boom (although this is being partially offset by strong residential and commercial construction activity);

partners. To correct for that bias, a more appropriate measure of a country's competitiveness is to compute the real effective exchange rate using unit labor costs instead of consumer prices. Unfortunately, statistics on labor costs are not available in The Bahamas or in other Caribbean countries that are The Bahamas' competitors.

${ }^{16}$ The most recent agreement for hotel workers provides for an average wage increase of 3-4 percent over the period 1998 to 2002. 
- a slowdown in credit to the private sector from the high rates of growth observed in $1997-98 ;{ }^{17}$ and

- the government's continued commitment to prudent fiscal policies.

\section{E. Conclusion}

\section{Maintaining a sound external position in The Bahamas depends on the} authorities' adherence to sound fiscal and credit policies. Over the past five years there has been a broad consensus that the authorities have been pursuing such policies, and that as a result economic performance and prospects have improved markedly. The recent widening of the external current account deficit stemmed largely from the imports of goods and services associated with the large investment projects that-to an important extent-reflected the government's sound policies; and indicators are that with the completion of most of these projects, the deficit has already begun to narrow in 1999, and will continue to do so over the medium term. It will be important, however, to ensure that a full accounting is made of the capital inflows to the private sector over the past two years, and the implications of these flows for private sector debt and debt service. The central bank's efforts in this area are expected to help clarify these issues, and ensure a close monitoring of private sector capital flows in future.

${ }^{17}$ Following the central bank's action in 1998 to tighten prudential controls over consumer credit, the annualized rate of growth of total credit to the private sector fell from 14 percent in June 1998 to 7 percent in June 1999. 
Figure 1. Bahamas: Ratio of Reserve Money to Foreign Assets

\section{(In percent)}

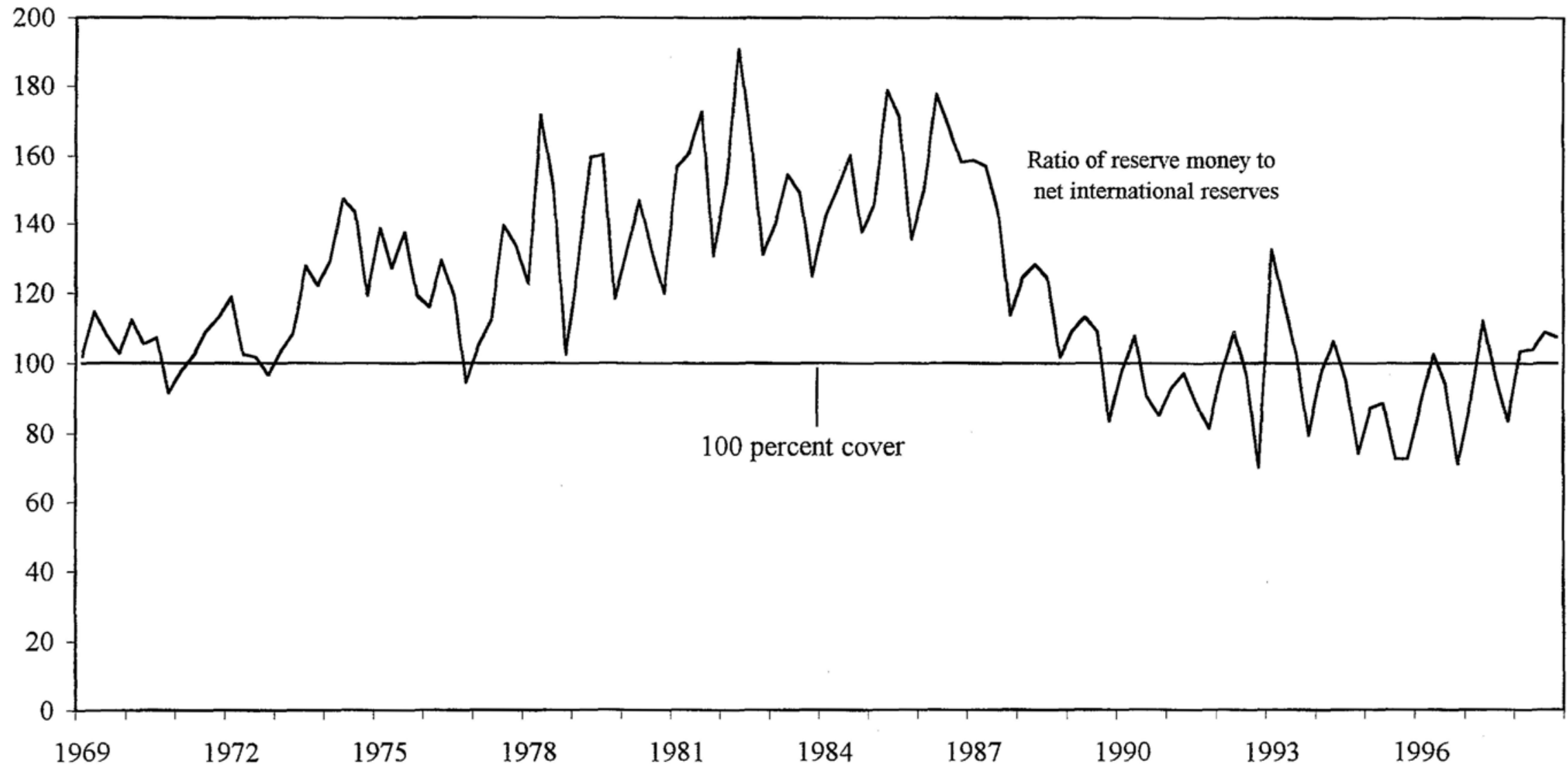

Sources: IMF International Financial Statistics; and Fund staff estimates. 


\section{Figure 2. Bahamas: Comparative Deposit Rates (In percent)}

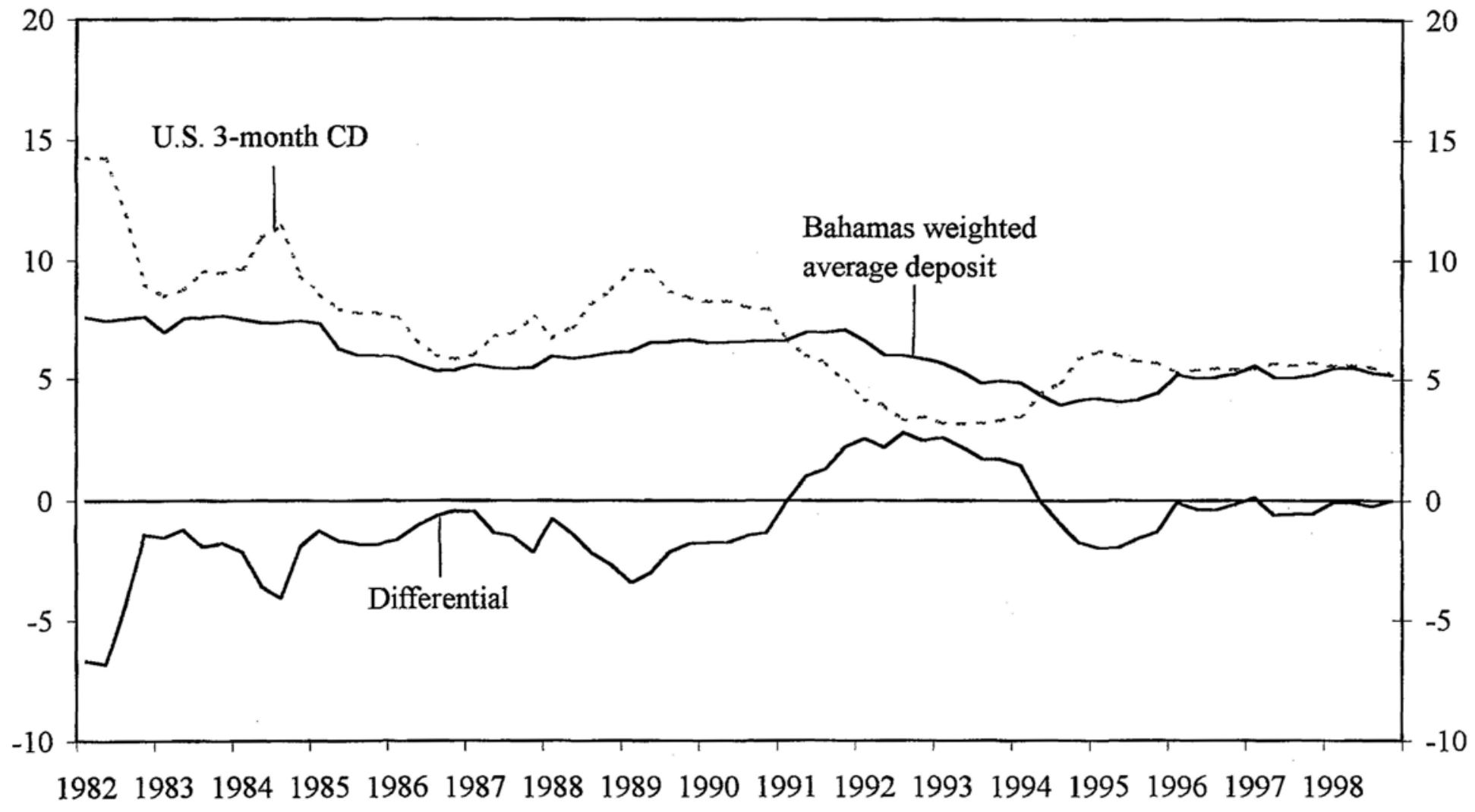

Sources: IMF International Financial Statistics; and Fund staff estimates. 
Figure 3. Bahamas: Comparative Treasury Bill Rates (In percent)

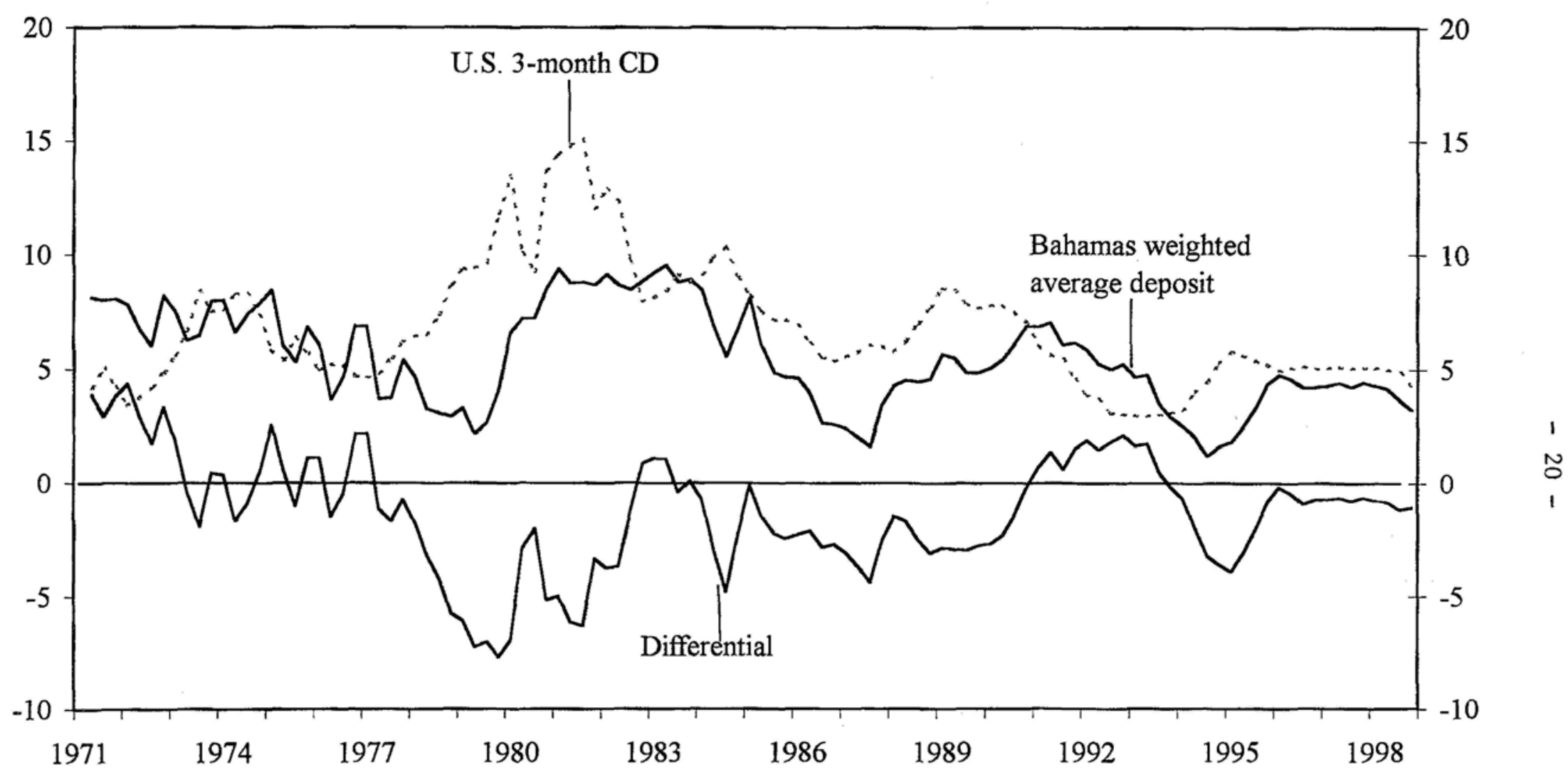

Sources: IMF International Financial Statistics; and Fund staff estimates. 


\section{Figure 4. Bahamas: Summary Balance of Payments (In percent of GDP)}

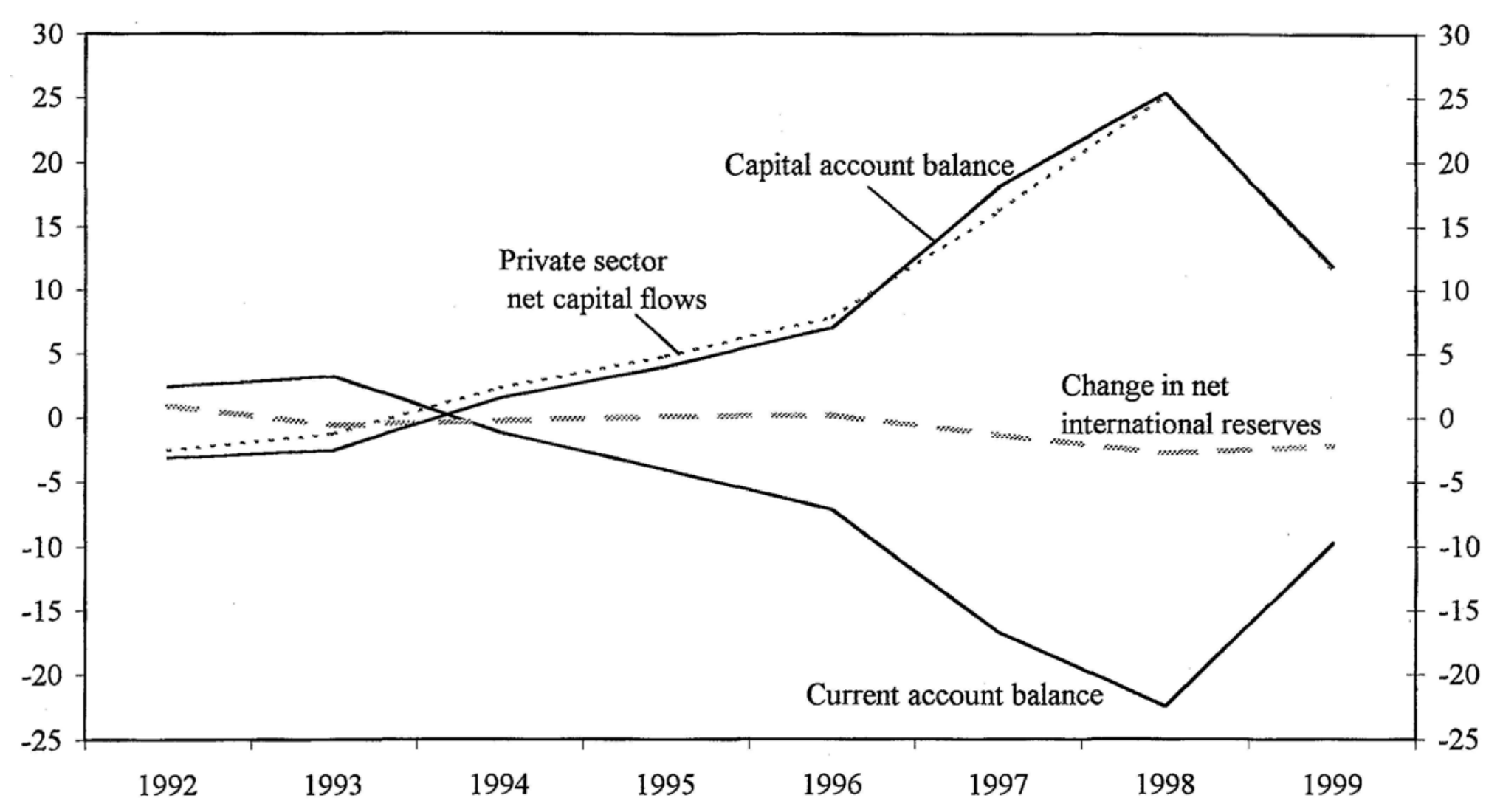

Source: The Bahamian authorities; and Fund staff estimates. 
Figure 5. Bahamas:Real Exchange Rate Developments

(Index 1990=100)

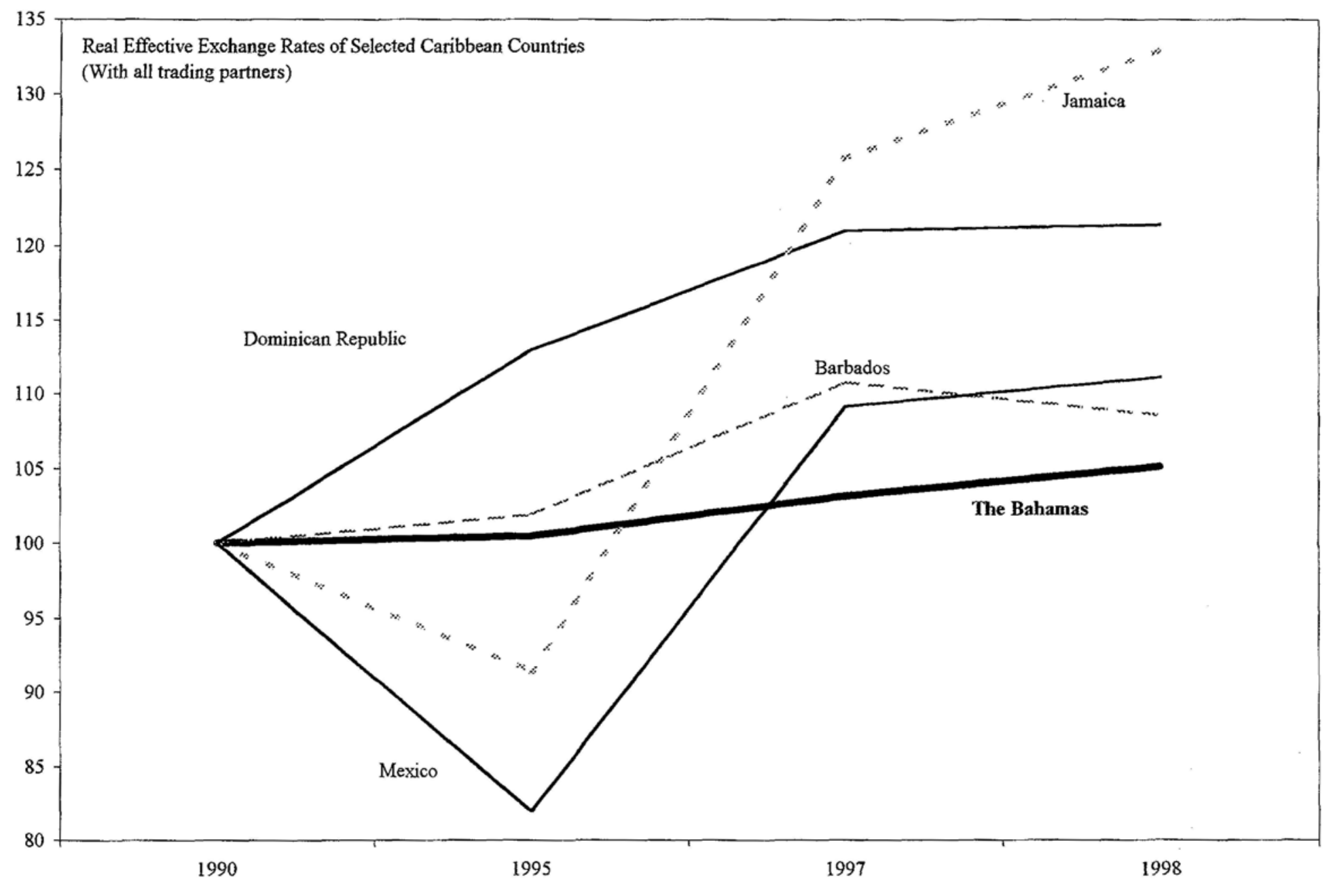

Source: Bahamian authorites; and Fund staff estimates. 
Table 1. The Bahamas: Geographic Distribution of Stopover Visitors 1/

\begin{tabular}{|c|c|c|c|c|c|}
\hline & 1993 & 1994 & 1995 & 1996 & 1997 \\
\hline \multicolumn{6}{|c|}{ (In percent) } \\
\hline Stopover visitors by country of residence & 100.0 & 100.0 & 100.0 & 100.0 & 100.0 \\
\hline Canada & 6.5 & 6.5 & 5.4 & 5.3 & 5.6 \\
\hline Europe & 8.9 & 7.2 & 7.2 & 7.8 & 8.1 \\
\hline United States & 81.3 & 82.7 & 83.2 & 82.1 & 81.0 \\
\hline Other $1 /$ & 3.3 & 3.5 & 4.3 & 4.8 & 5.3 \\
\hline \multicolumn{6}{|c|}{ (Percentage change) } \\
\hline \multicolumn{6}{|l|}{ Stopover arrivals } \\
\hline Canada & 6.4 & 3.9 & 5.4 & 2.2 & -0.9 \\
\hline Europe & 9.0 & 17.6 & 4.8 & 11.0 & 2.2 \\
\hline United States & 7.2 & 3.7 & 6.0 & 0.9 & -2.3 \\
\hline Other & -3.1 & 7.3 & 29.4 & 14.2 & 8.9 \\
\hline \multicolumn{6}{|c|}{ (In nights) } \\
\hline Average length of stay & 6.3 & 6.3 & 6.2 & 6.3 & 6.4 \\
\hline Canada & 7.7 & 7.9 & 8.1 & 6.3 & 6.4 \\
\hline Europe & 9.3 & 10.0 & 9.6 & 9.6 & 9.9 \\
\hline United States & 5.2 & 5.3 & 5.1 & 5.0 & 4.9 \\
\hline Other & 6.2 & 6.1 & 6.4 & 6.6 & 7.3 \\
\hline
\end{tabular}

Source: Ministry of tourism.

1/ The other main countries are Argentina, Australia, Brazil, Colombia, Jamaica, Japan, Mexico, and Venezuela. 
Table 2. The Bahamas: Value of Construction Starts and Completions 1/ (In millions of Bahamian dollars)

\begin{tabular}{lrrrrr}
\hline & 1993 & 1994 & 1995 & 1996 & 1997 \\
\hline Construction starts & 121.0 & 175.3 & 119.3 & $\mathbf{1 8 2 . 2}$ & $\mathbf{4 5 8 . 6}$ \\
Residential & 100.8 & 84.9 & 100.2 & 117.7 & 111.8 \\
New Providence & 78.4 & 69.9 & 73.3 & 80.7 & 82.2 \\
Grand Bahama & 22.4 & 14.9 & 26.9 & 37.0 & 29.6 \\
Commercial and industrial & 20.2 & 89.7 & 18.2 & 64.3 & 346.3 \\
New Providence & 12.6 & 74.8 & 12.9 & 30.9 & 333.8 \\
Grand Bahama & 7.6 & 14.9 & 5.2 & 33.4 & 12.5 \\
Government & 0.0 & 0.7 & 0.9 & 0.3 & 0.5 \\
& & & & & \\
Construction completions & 129.6 & 185.9 & 109.9 & 156.6 & 171.0 \\
Residential & 78.9 & 85.3 & 77.7 & 91.6 & 127.3 \\
New Providence & 64.1 & 70.6 & 58.4 & 66.4 & 89.3 \\
Grand Bahama & 14.8 & 14.7 & 19.3 & 25.2 & 38.0 \\
Commercial and industrial & 45.0 & 89.5 & 20.8 & 63.3 & 43.5 \\
New Providence & 27.1 & 75.3 & 15.1 & 32.3 & 19.9 \\
Grand Bahama & 17.9 & 14.2 & 5.8 & 31.0 & 23.6 \\
Government & 5.6 & 11.1 & 11.4 & 1.7 & 0.2 \\
\hline
\end{tabular}

Source: Central Bank of The Bahamas.

1/ The data refer to activity only in New Providence and Grand Bahama. 
Table 3. The Bahamas: Generation and Sale of Electricity

\begin{tabular}{|c|c|c|c|c|c|}
\hline & \multirow[b]{2}{*}{ Generated } & \multicolumn{4}{|c|}{ Units Sold } \\
\hline & & Residential & $\begin{array}{c}\text { Commercial \& } \\
\text { Industrial }\end{array}$ & $\begin{array}{c}\text { Street } \\
\text { Lighting }\end{array}$ & $\begin{array}{l}\text { Total } \\
\text { Sales }\end{array}$ \\
\hline \multicolumn{6}{|c|}{ (In millions of megawatt hours) } \\
\hline $\begin{array}{l}1993 \\
1994 \\
1995 \\
1996 \\
1997\end{array}$ & $\begin{array}{l}1,167 \\
1,228 \\
1,254 \\
1,290 \\
1,364\end{array}$ & $\begin{array}{l}346 \\
381 \\
398 \\
419 \\
446\end{array}$ & $\begin{array}{l}632 \\
665 \\
679 \\
711 \\
719\end{array}$ & $\begin{array}{l}5 \\
7 \\
7 \\
8 \\
8\end{array}$ & $\begin{array}{r}984 \\
1,053 \\
1,085 \\
1,137 \\
1,173\end{array}$ \\
\hline $\begin{array}{l}1996 \\
\text { I } \\
\text { II } \\
\text { III } \\
\text { IV }\end{array}$ & $\begin{array}{l}286 \\
328 \\
361 \\
315\end{array}$ & $\begin{array}{r}94 \\
101 \\
120 \\
103\end{array}$ & $\begin{array}{l}159 \\
178 \\
199 \\
175\end{array}$ & $\begin{array}{l}2 \\
2 \\
2 \\
2\end{array}$ & $\begin{array}{l}255 \\
280 \\
321 \\
281\end{array}$ \\
\hline $\begin{array}{l}1997 \\
\text { I } \\
\text { II } \\
\text { III } \\
\text { IV }\end{array}$ & $\begin{array}{l}305 \\
336 \\
384 \\
339\end{array}$ & $\begin{array}{r}93 \\
111 \\
131 \\
111\end{array}$ & $\begin{array}{l}155 \\
180 \\
200 \\
184\end{array}$ & $\begin{array}{l}2 \\
2 \\
2 \\
2\end{array}$ & $\begin{array}{l}250 \\
293 \\
332 \\
297\end{array}$ \\
\hline $\begin{array}{l}1998 \\
\text { I } \\
\text { II } \\
\text { III }\end{array}$ & $\begin{array}{l}305 \\
372 \\
430\end{array}$ & $\begin{array}{r}83 \\
93 \\
151\end{array}$ & $\begin{array}{l}159 \\
173 \\
233\end{array}$ & $\begin{array}{l}2 \\
2 \\
2\end{array}$ & $\begin{array}{l}264 \\
292 \\
386\end{array}$ \\
\hline \multicolumn{6}{|c|}{ (Annual percentage change) } \\
\hline $\begin{array}{l}1993 \\
1994 \\
1995 \\
1996 \\
1997\end{array}$ & $\begin{array}{l}4.7 \\
5.1 \\
2.2 \\
2.9 \\
5.7\end{array}$ & $\begin{array}{r}6.6 \\
10.1 \\
4.4 \\
5.3 \\
6.4\end{array}$ & $\begin{array}{l}5.1 \\
5.1 \\
2.2 \\
4.7 \\
1.1\end{array}$ & $\begin{array}{r}-63.4 \\
30.3 \\
5.4 \\
14.3 \\
0.4\end{array}$ & $\begin{array}{l}4.5 \\
7.0 \\
3.0 \\
4.8 \\
3.2\end{array}$ \\
\hline $\begin{array}{l}1996 \\
\text { I } \\
\text { II } \\
\text { III } \\
\text { IV }\end{array}$ & $\begin{array}{l}7.1 \\
0.0 \\
2.8 \\
2.6\end{array}$ & $\begin{array}{l}6.8 \\
0.0 \\
8.1 \\
3.0\end{array}$ & $\begin{array}{l}8.2 \\
3.5 \\
6.4 \\
0.0\end{array}$ & $\begin{array}{l}0.0 \\
0.0 \\
0.0 \\
0.0\end{array}$ & $\begin{array}{l}8.1 \\
1.8 \\
7.4 \\
2.2\end{array}$ \\
\hline $\begin{array}{l}1997 \\
\text { I } \\
\text { II } \\
\text { III } \\
\text { IV }\end{array}$ & $\begin{array}{l}6.7 \\
2.4 \\
6.4 \\
7.6\end{array}$ & $\begin{array}{r}-1.0 \\
9.9 \\
9.2 \\
7.8\end{array}$ & $\begin{array}{r}-2.5 \\
1.1 \\
0.5 \\
5.1\end{array}$ & $\begin{array}{l}4.3 \\
4.8 \\
4.2 \\
3.1\end{array}$ & $\begin{array}{r}-2.0 \\
4.6 \\
3.4 \\
5.9\end{array}$ \\
\hline $\begin{array}{l}1998 \\
\text { I } \\
\text { II } \\
\text { III }\end{array}$ & $\begin{array}{r}0.0 \\
10.7 \\
26.8\end{array}$ & $\begin{array}{r}-10.8 \\
-16.2 \\
36.0\end{array}$ & $\begin{array}{r}2.6 \\
-3.9 \\
26.6\end{array}$ & $\begin{array}{r}1.0 \\
4.0 \\
10.1\end{array}$ & $\begin{array}{r}5.6 \\
-0.4 \\
16.3\end{array}$ \\
\hline
\end{tabular}

Source: Central Bank of The Bahamas. 
Table 4. The Bahamas: Retail Price Index for New Providence

(October/November 1995=100)

\begin{tabular}{|c|c|c|c|c|c|c|c|c|c|c|}
\hline & Food & Housing & $\begin{array}{l}\text { Clothing } \\
\text { and } \\
\text { Footwear }\end{array}$ & $\begin{array}{c}\text { Transpor- } \\
\text { tation }\end{array}$ & $\begin{array}{r}\text { Medical } \\
\text { Care and } \\
\text { Health }\end{array}$ & $\begin{array}{l}\text { Recreation } \\
\text { and } \\
\text { Services }\end{array}$ & $\begin{array}{c}\text { Furniture } \\
\text { and } \\
\text { Household }\end{array}$ & $\begin{array}{l}\text { Edu- } \\
\text { cation }\end{array}$ & Other & $\begin{array}{r}\text { All } \\
\text { Items }\end{array}$ \\
\hline Weight & 13.8 & 32.8 & 5.9 & 14.8 & 4.4 & 4.9 & 8.9 & 5.3 & 9.2 & 100.0 \\
\hline \multicolumn{11}{|c|}{ Annual average percentage change } \\
\hline 1990 & 5.4 & 17.3 & -1.3 & -9.7 & -9.5 & -0.6 & -1.2 & 2.2 & -4.6 & 1.7 \\
\hline 1991 & 8.6 & 0.3 & 7.3 & 8.3 & 4.8 & 14.1 & 7.2 & 13.0 & 15.9 & 7.4 \\
\hline 1992 & 2.1 & 3.7 & 4.5 & 10.8 & 1.9 & 1.2 & 6.8 & 10.7 & 6.9 & 5.6 \\
\hline 1993 & 0.7 & 4.2 & 2.4 & 2.7 & 18.5 & 0.2 & 1.3 & 0.3 & 3.1 & 2.7 \\
\hline 1994 & -0.4 & 0.9 & 2.7 & 2.2 & 6.5 & -0.1 & 1.9 & 0.6 & 1.2 & 1.3 \\
\hline 1995 & 2.0 & 1.1 & 0.2 & 4.4 & 3.5 & 0.0 & 3.1 & 0.6 & 1.3 & 2.2 \\
\hline 1996 & 2.5 & 1.9 & 2.8 & 0.4 & 2.1 & 0.7 & 1.1 & -0.1 & -0.2 & 1.4 \\
\hline 1997 & 1.7 & 0.2 & 1.9 & 0.7 & 1.2 & 2.2 & 1.2 & -3.5 & 0.7 & 0.6 \\
\hline 1998 & 2.2 & -0.1 & 1.7 & 0.7 & 2.4 & 2.0 & 1.2 & 9.7 & 0.6 & 1.4 \\
\hline
\end{tabular}

(Annual percentage change, end of period)

\begin{tabular}{|c|c|c|c|c|c|c|c|c|c|c|}
\hline 1990 & & & & & & & & & & \\
\hline I & 2.3 & 3.0 & 2.2 & 0.7 & 3.6 & 0.8 & 1.5 & 0.5 & -0.3 & 1.8 \\
\hline II & 2.3 & 1.8 & 2.5 & 0.2 & 1.5 & 0.9 & 1.7 & 0.5 & -0.5 & 1.3 \\
\hline III & 3.0 & 1.9 & 3.2 & 0.4 & 1.3 & -0.6 & 0.5 & 0.1 & 0.6 & 1.4 \\
\hline IV & 2.6 & 1.6 & 3.1 & 0.2 & 1.4 & 1.5 & 0.3 & -2.5 & -0.6 & 1.1 \\
\hline
\end{tabular}

\begin{tabular}{lrrrrrrrrrr}
1997 & & & & & & & & & & \\
I & 1.9 & 0.2 & 0.6 & 0.2 & 1.3 & 2.4 & 0.1 & -2.4 & -0.6 & 0.3 \\
II & 1.7 & 0.4 & 0.3 & 0.9 & 0.8 & 3.3 & 1.5 & -5.3 & 1.4 & 0.7 \\
III & 1.0 & 0.2 & -0.2 & 0.8 & 0.9 & 2.5 & 1.5 & -5.3 & 1.8 & 0.5 \\
IV & 1.9 & -0.2 & 0.5 & 1.6 & 2.1 & 0.6 & 1.8 & -1.1 & 1.7 & 0.8 \\
& & & & & & & & & & \\
1998 & & & & & & & & & & \\
I & 2.4 & -0.2 & 1.5 & 1.4 & 2.7 & 0.9 & 2.0 & -0.9 & 1.7 & 1.1 \\
II & 2.7 & -0.7 & 1.7 & 0.8 & 2.4 & 0.0 & 0.5 & 11.4 & -0.1 & 1.1 \\
III & 2.2 & -0.3 & 1.8 & -0.5 & 2.1 & 4.0 & 0.9 & 14.5 & -0.4 & 1.3 \\
IV & 1.7 & 0.7 & 2.3 & -0.5 & 2.0 & 5.1 & 1.0 & 17.4 & -0.2 & 1.9 \\
\hline
\end{tabular}

Source: Central Bank of The Bahamas. 
Table 5. The Bahamas: Summary Operations of the Nonfinancial Public Sector

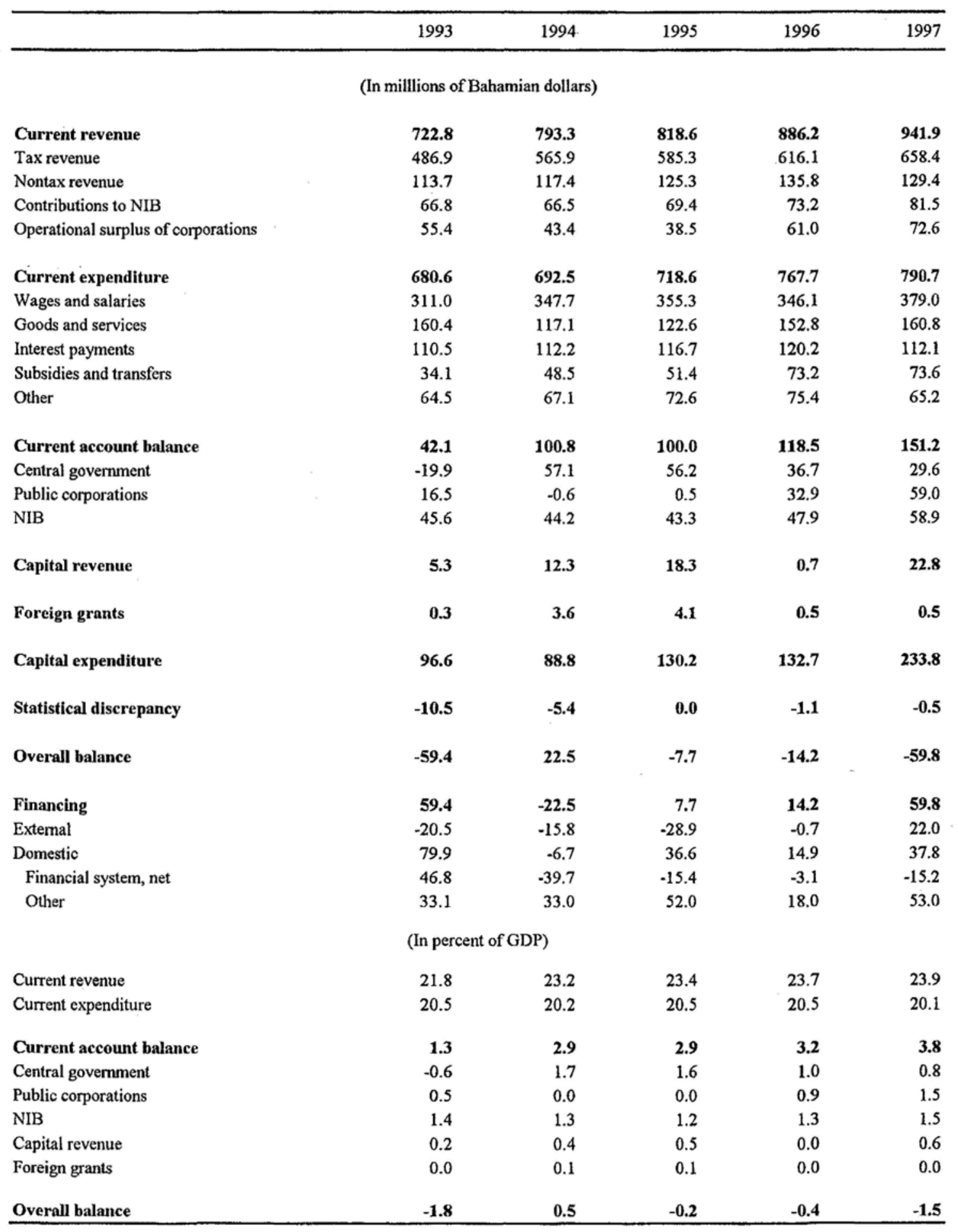

Sources: Ministry of Finance; and Fund staff estimates. 
Table 6. The Bahamas: Summary Central Government Operations

\begin{tabular}{|c|c|c|c|c|c|}
\hline & 1994 & 1995 & 1996 & 1997 & 1998 \\
\hline \multicolumn{6}{|c|}{ (In millions of Bahamian dollars) } \\
\hline Current revenue & 639.3 & 657.0 & 686.7 & 728.4 & 761.1 \\
\hline Tax revenue & 565.9 & 585.3 & 616.1 & 658.4 & 681.7 \\
\hline Nontax revenue & 73.4 & 71.7 & 70.6 & 70.0 & 79.4 \\
\hline Current expenditure & 582.2 & 600.8 & 650.0 & 698.8 & 725.1 \\
\hline Wages and salaries & 336.8 & 344.4 & 333.7 & 366.9 & 383.9 \\
\hline Goods and services & 112.8 & 116.8 & 146.7 & 154.4 & 163.2 \\
\hline Interest payments & 77.3 & 81.8 & 87.3 & 94.0 & 99.0 \\
\hline Subsidies and transfers & 55.3 & 57.8 & 82.3 & 83.5 & 79.0 \\
\hline Current account balance & 57.1 & 56.2 & 36.7 & 29.6 & 36.0 \\
\hline Capital revenue & 2.8 & 9.0 & 0.0 & 0.8 & 0.5 \\
\hline Foreign grants & 3.6 & 4.1 & 0.5 & 0.5 & 0.5 \\
\hline Capital expenditure and net Iending & 93.4 & 102.1 & 99.6 & 165.7 & 117.5 \\
\hline Fixed capital formation & 46.4 & 63.3 & 60.8 & 117.6 & 75.4 \\
\hline Capital transfers & 51.0 & 39.8 & 39.8 & 48.3 & 42.4 \\
\hline Net lending & -4.0 & -1.0 & -1.0 & -0.2 & -0.3 \\
\hline Statistical discrepancy & -5.4 & 0.1 & -1.1 & -0.5 & -0.2 \\
\hline Overall balance & -35.3 & -32.7 & -63.5 & -135.3 & -80.7 \\
\hline Total financing & 35.3 & 32.7 & 63.5 & 135.3 & 80.7 \\
\hline Foreign financing & -8.5 & -10.2 & -13.8 & 13.7 & -6.0 \\
\hline Domestic financing & 43.8 & 42.9 & 77.3 & 121.6 & 86.7 \\
\hline Financial system, net & -24.5 & 11.6 & -2.0 & -1.9 & 32.4 \\
\hline Nonfinancial system & 68.3 & 31.3 & 79.3 & 123.5 & 54.3 \\
\hline \multicolumn{6}{|c|}{ (In percent of GDP) } \\
\hline Current revenue & 18.7 & 18.8 & 18.4 & 18.5 & 18.4 \\
\hline Tax revenue & 16.5 & 16.7 & 16.5 & 16.7 & 16.5 \\
\hline Nontax revenue & 2.1 & 2.0 & 1.9 & 1.8 & 1.9 \\
\hline Current expenditure & 17.0 & 17.1 & 17.4 & 17.7 & 17.6 \\
\hline Wages and salaries & 9.8 & 9.8 & 8.9 & 9.3 & 9.3 \\
\hline Goods and services & 3.3 & 3.3 & 3.9 & 3.9 & 4.0 \\
\hline Interest payments & 2.3 & 2.3 & 2.3 & 2.4 & 2.4 \\
\hline Subsidies and transfers & 1.6 & 1.6 & 2.2 & 2.1 & 1.9 \\
\hline Current account balance & 1.7 & 1.6 & 1.0 & 0.8 & 0.9 \\
\hline Capital revenue & 0.1 & 0.3 & 0.0 & 0.0 & 0.0 \\
\hline Foreign grants & 0.1 & 0.1 & 0.0 & 0.0 & 0.0 \\
\hline Capital expenditure & 2.7 & 2.9 & 2.7 & 4.2 & 2.8 \\
\hline Capital formation & 1.4 & 1.8 & 1.6 & 3.0 & 1.8 \\
\hline Capital transfers & 1.5 & 1.1 & 1.0 & 1.2 & 1.0 \\
\hline Statistical discrepancy & -0.2 & 0.0 & 0.0 & 0.0 & 0.0 \\
\hline Overall balance & -1.0 & -0.9 & -1.7 & -3.4 & -2.0 \\
\hline Financing & 1.0 & 0.9 & 1.7 & 3.4 & 2.0 \\
\hline Foreign financing & -0.2 & -0.3 & -0.4 & 0.3 & -0.1 \\
\hline Domestic financing & 1.3 & 1.2 & 2.1 & 3.1 & 2.1 \\
\hline Financial system, net & -0.7 & 0.3 & -0.2 & 0.0 & 0.8 \\
\hline Other & 2.0 & 0.9 & 2.2 & 3.1 & 1.3 \\
\hline
\end{tabular}

Sources: Ministry of Finance; and Fund staff estimates. 
Table 7. The Bahamas: Central Government Revenue

\begin{tabular}{|c|c|c|c|c|c|}
\hline & 1994 & 1995 & 1996 & 1997 & 1998 \\
\hline \multicolumn{6}{|c|}{ (In millions of Bahamian dollars) } \\
\hline Total revenue & 645.7 & 670.1 & 687.2 & 729.7 & 762.1 \\
\hline Total current revenue & 639.3 & 657.0 & 686.7 & 728.4 & 761.1 \\
\hline Tax revenue & 565.9 & 585.3 & 616.1 & 658.4 & 681.7 \\
\hline Taxes on international trade & 383.9 & 393.3 & 404.7 & 437.0 & 448.0 \\
\hline Import duties & 307.1 & 312.5 & 319.6 & 345.6 & 347.4 \\
\hline Stamp duty & 67.6 & 72.3 & 73.9 & 80.9 & 87.9 \\
\hline Export duty & 9.2 & 8.5 & 11.2 & 10.5 & 12.7 \\
\hline Tourism taxes & 62.8 & 58.2 & 60.0 & 65.6 & 60.3 \\
\hline Departure tax & 55.2 & 50.1 & 49.6 & 52.2 & 48.4 \\
\hline Hotel occupancy tax & 5.3 & 6.5 & 8.9 & 9.3 & 9.4 \\
\hline Ticket tax & 2.3 & 1.6 & 1.5 & 4.1 & 2.5 \\
\hline Miscellaneous taxes & 119.3 & 130.5 & 150.7 & 152.3 & 170.7 \\
\hline Company fees & 29.3 & 33.3 & 34.1 & 34.7 & 39.1 \\
\hline Motor vehicle tax & 15.4 & 13.1 & 12.3 & 13.6 & 12.5 \\
\hline Property tax & 19.2 & 19.1 & 32.0 & 24.8 & 30.5 \\
\hline Stamp tax & 38.7 & 48.7 & 52.3 & 59.7 & 70.6 \\
\hline Gaming tax & 16.6 & 16.3 & 20.0 & 19.5 & 18.0 \\
\hline Other & 0.0 & 3.4 & 0.7 & 3.5 & 2.7 \\
\hline Nontax revenue & 73.4 & 71.7 & 70.6 & 70.0 & 79.4 \\
\hline Administrative fees and charges & 44.7 & 46.3 & 44.5 & 46.1 & 49.8 \\
\hline Property and service income & 28.7 & 24.2 & 25.4 & 23.3 & 28.8 \\
\hline Other & 0.0 & 1.2 & 0.7 & 0.6 & 0.8 \\
\hline Capital revenue & 2.8 & 9.0 & 0.0 & 0.8 & 0.5 \\
\hline Foreign grants & 3.6 & 4.1 & 0.5 & 0.5 & 0.5 \\
\hline \multicolumn{6}{|c|}{ (Annual percentage change) } \\
\hline Total revenue & 17.1 & 3.8 & 2.6 & 6.2 & 4.4 \\
\hline Tax revenue & 16.2 & 3.4 & 5.3 & 6.9 & 3.5 \\
\hline Taxes on international trade & 21.2 & 2.4 & 2.9 & 8.0 & 2.5 \\
\hline Tourism taxes & 6.2 & -7.4 & 3.1 & 9.3 & -8.1 \\
\hline Miscellaneous taxes & 7.5 & 9.4 & 15.5 & 1.1 & 12.1 \\
\hline Nontax revenue & 13.6 & -2.2 & -1.5 & -0.9 & 13.4 \\
\hline \multicolumn{6}{|c|}{ (In percent of total current revenue) } \\
\hline Total current revenue & 100.0 & 100.0 & 100.0 & 100.0 & 100.0 \\
\hline Tax revenue & 88.5 & 89.1 & 89.7 & 90.4 & 89.6 \\
\hline Taxes on international trade & 60.0 & 59.9 & 58.9 & 60.0 & 58.9 \\
\hline Import duties & 48.0 & 47.6 & 46.5 & 47.4 & 45.6 \\
\hline Stamp duty & 10.6 & 11.0 & 10.8 & 11.1 & 11.5 \\
\hline Export duty & 1.4 & 1.3 & 1.6 & 1.4 & 1.7 \\
\hline Tourism taxes & 9.8 & 8.9 & 8.7 & 9.0 & 7.9 \\
\hline Departure tax & 8.6 & 7.6 & 7.2 & 7.2 & 6.4 \\
\hline Hotel occupancy tax & 0.8 & 1.0 & 1.3 & 1.3 & 1.2 \\
\hline Ticket tax & 0.4 & 0.2 & 0.2 & 0.6 & 0.3 \\
\hline Miscellaneous taxes & 18.7 & 19.9 & 21.9 & 20.9 & 22.4 \\
\hline Company fees & 4.6 & 5.1 & 5.0 & 4.8 & 5.1 \\
\hline Motor vehicle tax & 2.4 & 2.0 & 1.8 & 1.9 & 1.6 \\
\hline Property tax & 3.0 & 2.9 & 4.7 & 3.4 & 4.0 \\
\hline Stamp tax & 6.1 & 7.4 & 7.6 & 8.2 & 9.3 \\
\hline Gaming tax & 2.6 & 2.5 & 2.9 & 2.7 & 2.4 \\
\hline Nontax revenue & 11.5 & 10.9 & 10.3 & 9.6 & 10.4 \\
\hline
\end{tabular}


Table 7. The Bahamas: Central Government Revenue

\begin{tabular}{|c|c|c|c|c|c|}
\hline & 1994 & 1995 & 1996 & 1997 & 1998 \\
\hline \multicolumn{6}{|c|}{ (In percent of GDP) } \\
\hline Total revenue & 18.8 & 19.1 & 18.4 & 18.5 & 18.4 \\
\hline Tax revenue & 16.5 & 16.7 & 16.5 & 16.7 & 16.5 \\
\hline Taxes on international trade & 11.2 & 11.2 & 10.8 & 11.1 & 10.9 \\
\hline Import duties & 9.0 & 8.9 & 8.5 & 8.8 & 8.4 \\
\hline Stamp duty & 2.0 & 2.1 & 2.0 & 2.1 & 2.1 \\
\hline Export duty & 0.3 & 0.2 & 0.3 & 0.3 & 0.3 \\
\hline Tourism taxes & 1.8 & 1.7 & 1.6 & 1.7 & 1.5 \\
\hline Departure tax & 1.6 & 1.4 & 1.3 & 1.3 & 1.2 \\
\hline Hotel occupancy tax & 0.2 & 0.2 & 0.2 & 0.2 & 0.2 \\
\hline Ticket tax & 0.1 & 0.0 & 0.0 & 0.1 & 0.1 \\
\hline Miscellaneous taxes & 3.5 & 3.7 & 4.0 & 3.9 & 4.1 \\
\hline Company fees & 0.9 & 1.0 & 0.9 & 0.9 & 0.9 \\
\hline Motor vehicle tax & 0.5 & 0.4 & 0.3 & 0.3 & 0.3 \\
\hline Property tax & 0.6 & 0.5 & 0.9 & 0.6 & 0.7 \\
\hline Stamp tax & 1.1 & 1.4 & 1.4 & 1.5 & 1.7 \\
\hline Gaming tax & 0.5 & 0.5 & 0.5 & 0.5 & 0.4 \\
\hline Nontax revenue & 2.1 & 2.0 & 1.9 & 1.8 & 1.9 \\
\hline Fees and charges & 1.3 & 1.3 & 1.2 & 1.2 & 1.2 \\
\hline Property income & 0.8 & 0.7 & 0.7 & 0.6 & 0.7 \\
\hline Capital revenue & 0.1 & 0.3 & 0.0 & 0.0 & 0.0 \\
\hline Foreign grants & 0.1 & 0.1 & 0.0 & 0.0 & 0.0 \\
\hline
\end{tabular}

Sources: Ministry of Finance; and Fund staff estimates. 
Table 8. The Bahamas: Central Government Expenditure

\begin{tabular}{|c|c|c|c|c|c|}
\hline & 1994 & 1995 & 1996 & 1997 & 1998 \\
\hline \multicolumn{6}{|c|}{ (In millions of Bahamian dollars) } \\
\hline Total expenditure & 675.6 & 702.9 & 749.6 & 864.5 & 842.6 \\
\hline Current expenditure & 582.2 & 600.8 & 650.0 & 698.8 & 725.1 \\
\hline Wages and salaries & 336.8 & 344.4 & 333.7 & 366.9 & 383.9 \\
\hline Goods and services & 112.8 & 116.8 & 146.7 & 154.4 & 163.2 \\
\hline Interest payments & 77.3 & 81.8 & 87.3 & 94.0 & 99.0 \\
\hline External & 5.7 & 7.9 & 8.4 & 7.1 & 8.9 \\
\hline Domestic & 71.6 & 73.9 & 78.9 & 86.9 & 90.1 \\
\hline Transfers and subsidies & 55.3 & 57.8 & 82.3 & 83.5 & 79.0 \\
\hline Public corporations & 1.5 & 1.5 & 2.5 & 1.3 & 0.9 \\
\hline NIB & 5.3 & 4.9 & 6.6 & 8.6 & 6.8 \\
\hline Pensions, excluding NIB & 30.3 & 31.7 & 34.0 & 38.3 & 41.9 \\
\hline Education & 2.7 & 10.6 & 11.2 & 13.3 & 14.5 \\
\hline Other & 18.2 & 9.1 & 28.0 & 22.0 & 14.9 \\
\hline Capital expenditure & 93.4 & 102.1 & 99.6 & 165.7 & 117.5 \\
\hline Fixed capital formation & 46.4 & 63.3 & 60.8 & 117.6 & 75.4 \\
\hline Public works & 23.3 & 48.4 & 40.8 & 73.3 & 31.6 \\
\hline Education & 7.0 & 4.9 & 4.7 & 15.9 & 19.1 \\
\hline Health & 2.8 & 1.1 & 1.6 & 6.6 & 5.5 \\
\hline Defense & 2.2 & 1.3 & 2.5 & 12.2 & 6.9 \\
\hline Other & 11.1 & 7.6 & 11.2 & 9.6 & 12.3 \\
\hline Capital transfers & 51.0 & 39.8 & 39.8 & 48.3 & 42.4 \\
\hline Bahamasair & 13.5 & 14.0 & 12.6 & 10.2 & 8.4 \\
\hline Hotel corporation & 22.2 & 13.3 & 7.7 & 16.1 & 4.8 \\
\hline BEC & 0.0 & 0.0 & 3.5 & 3.0 & 4.0 \\
\hline Broadcasting corporation & 3.1 & 3.6 & 8.3 & 4.6 & 7.0 \\
\hline Water and sewerage corporation & 6.4 & 8.9 & 6.5 & 11.8 & 15.3 \\
\hline Bahamas Development Bank & 2.5 & 0.0 & 1.2 & 2.0 & 2.7 \\
\hline Mortgage corporation & 2.6 & 0.0 & 0.0 & 0.1 & 0.1 \\
\hline Caribbean Development Bank & 0.6 & 0.0 & 0.0 & 0.0 & 0.0 \\
\hline Net lending & -4.0 & -1.0 & -1.0 & -0.2 & -0.3 \\
\hline
\end{tabular}

(Annual percentage change)

\section{Total expenditure \\ Current expenditure \\ Wages and salaries \\ Goods and services \\ Interest payments \\ External \\ Domestic}

Transfers and subsidies

Capital expenditure

$\begin{array}{rrrrr}2.6 & 4.0 & 6.6 & 15.3 & -2.5 \\ & & & & \\ 1.9 & 3.2 & 8.2 & 7.5 & 3.8 \\ 12.0 & 2.2 & -3.1 & 9.9 & 4.6 \\ -27.3 & 3.6 & 25.6 & 5.2 & 5.7 \\ 0.3 & 5.8 & 6.7 & 7.7 & 5.3 \\ -24.3 & 38.1 & 6.3 & -15.5 & 25.4 \\ 3.0 & 3.2 & 6.8 & 10.1 & 3.7 \\ 44.3 & 4.6 & 42.4 & 1.5 & -5.4 \\ & & & & \\ 7.2 & 9.3 & -2.4 & 66.4 & -29.1\end{array}$


Table 8. The Bahamas: Central Government Expenditure

\begin{tabular}{|c|c|c|c|c|c|}
\hline & 1994 & 1995 & 1996 & 1997 & 1998 \\
\hline \multicolumn{6}{|c|}{ (In percent of GDP) } \\
\hline Total expenditure & 19.7 & 20.1 & 20.0 & 21.9 & 20.4 \\
\hline Current expenditure & 17.0 & 17.1 & 17.4 & 17.7 & 17.6 \\
\hline Wages and salaries & 9.8 & 9.8 & 8.9 & 9.3 & 9.3 \\
\hline Goods and services & 3.3 & 3.3 & 3.9 & 3.9 & 4.0 \\
\hline Interest payments & 2.3 & 2.3 & 2.3 & 2.4 & 2.4 \\
\hline External & 0.2 & 0.2 & 0.2 & 0.2 & 0.2 \\
\hline Domestic & 2.1 & 2.1 & 2.1 & 2.2 & 2.2 \\
\hline Transfers and subsidies & 1.6 & 1.6 & 2.2 & 2.1 & 1.9 \\
\hline Capital expenditure & 2.7 & 2.9 & 2.7 & 4.2 & 2.8 \\
\hline Fixed capital formation & 1.4 & 1.8 & 1.6 & 3.0 & 1.8 \\
\hline Capital transfers & 1.5 & 1.1 & 1.1 & 1.2 & 1.0 \\
\hline Net lending & -0.1 & 0.0 & 0.0 & 0.0 & 0.0 \\
\hline
\end{tabular}

Sources: Ministry of Finance; and Fund staff estimates. 
Table 9. The Bahamas: Number of Employees in the Central Government

\begin{tabular}{|c|c|c|c|c|c|}
\hline & 1994 & 1995 & 1996 & 1997 & 1998 \\
\hline Total & 18,488 & 19,068 & 19,297 & 17,831 & 17,710 \\
\hline Education & 4,634 & 4,907 & 4,907 & 4,353 & 4,340 \\
\hline Police, prisons, and defense $1 /$ & 3,787 & 3,926 & 3,998 & 3,667 & 3,654 \\
\hline Health & 4,140 & 4,150 . & 4,138 & 4,028 & 4,066 \\
\hline Public works & 1,583 & 1,562 & 1,355 & 848 & 783 \\
\hline Customs & 454 & 512 & 533 & 529 & 519 \\
\hline Ministry of finance and treasury & 322 & 354 & 343 & 259 & 260 \\
\hline Post, aviation, and marine & 632 & 637 & 637 & 657 & 671 \\
\hline Current expenditure & 462 & 433 & 448 & 378 & 364 \\
\hline Immigration & 254 & 256 & 289 & 297 & 277 \\
\hline Agriculture and fisheries & 359 & 333 & 329 & 294 & 320 \\
\hline Statistics & 75 & 91 & 80 & 80 & 74 \\
\hline Youth and social services $2 /$ & 509 & 508 & 523 & 514 & 507 \\
\hline Other & 1,277 & 1,399 & 1,717 & 1,927 & 1,875 \\
\hline \multicolumn{6}{|c|}{ (Annual percentage change) } \\
\hline Total & 0.1 & 3.1 & 1.2 & -7.6 & -0.7 \\
\hline Education & 0.4 & 5.9 & 0.0 & -11.3 & -0.3 \\
\hline Police, prisons, and defense $1 /$ & 2.4 & 3.7 & 1.8 & -8.3 & -0.4 \\
\hline Health & -0.2 & 0.2 & -0.3 & -2.7 & 0.9 \\
\hline Public works & 3.3 & -1.3 & -13.3 & -37.4 & -7.7 \\
\hline Post, aviation, and marine & -14.6 & 0.8 & 0.0 & 3.1 & 2.1 \\
\hline Tourism 2/ & -14.3 & -6.3 & 3.5 & -15.6 & -3.7 \\
\hline Other & 12.5 & 9.6 & 22.7 & 12.2 & -2.7 \\
\hline \multicolumn{6}{|c|}{ (In percent of total) } \\
\hline Total & 100.0 & 100.0 & 100.0 & 100.0 & 100.0 \\
\hline Education & 25.1 & 25.7 & 25.7 & 25.4 & 24.4 \\
\hline Police, prisons, and defense $1 /$ & 20.5 & 20.5 & 20.6 & 20.7 & 20.6 \\
\hline Health & 22.4 & 21.8 & 21.8 & 21.4 & 22.6 \\
\hline Public works & 8.6 & 8.2 & 8.2 & 7.0 & 4.8 \\
\hline Customs & 2.5 & 2.7 & 2.7 & 2.8 & 3.0 \\
\hline Ministry of finance and treasury & 1.7 & 1.9 & 1.9 & 1.8 & 1.5 \\
\hline Post, aviation, and marine & 3.4 & 3.3 & 3.3 & 3.3 & 3.7 \\
\hline Tourism 2/ & 2.5 & 2.3 & 2.3 & 2.3 & 2.1 \\
\hline Immigration & 1.4 & 1.3 & 1.3 & 1.5 & 1.7 \\
\hline Agriculture and fisheries & 1.9 & 1.7 & 1.7 & 1.7 & 1.6 \\
\hline Statistics & 0.4 & 0.5 & 0.5 & 0.4 & 0.4 \\
\hline Youth and social services & 2.8 & 2.7 & 2.7 & 2.7 & 2.9 \\
\hline Other & 6.9 & 7.3 & 7.3 & 8.9 & 10.8 \\
\hline
\end{tabular}

Sources: Ministry of Finance; and Fund staff estimates.

1/ Including the judicial system.

2/ Includes industrial schools. 
Table 10. The Bahamas: Operations of the National Insurance Board (NIB)

\begin{tabular}{|c|c|c|c|c|c|}
\hline & 1994 & 1995 & 1996 & 1997 & 1998 \\
\hline \multicolumn{6}{|c|}{ (In millions of Bahamian dollars) } \\
\hline Revenue & 115.8 & 120.7 & 129.1 & 142.5 & 147.2 \\
\hline Contributions & 66.5 & 69.4 & 73.2 & 81.5 & 82.7 \\
\hline Investment income & 44.0 & 46.4 & 50.9 & 56.1 & 59.6 \\
\hline Transfers from central government & 5.3 & 4.9 & 4.9 & 4.9 & 4.9 \\
\hline Expenditure & 74.9 & 78.8 & 84.0 & 89.0 & 87.0 \\
\hline Current expenditure & 72.3 & 77.4 & 81.2 & 83.6 & 81.0 \\
\hline Wages and salaries & 10.9 & 10.9 & 12.4 & 12.1 & 12.6 \\
\hline Benefit payments & 56.4 & 60.7 & 62.7 & 65.1 & 61.3 \\
\hline Short term & 10.0 & 10.7 & 10.6 & 10.7 & 10.6 \\
\hline Long term & 43.9 & 50.0 & 52.1 & 54.4 & 50.7 \\
\hline Retirement & 19.9 & 21.7 & 23.6 & 25.1 & 25.6 \\
\hline Old age (noncontributory) & 10.8 & 10.0 & 9.5 & 8.6 & 8.7 \\
\hline Other & 13.1 & 15.2 & 16.1 & 16.8 & 13.2 \\
\hline Industrial & 2.5 & 3.1 & 3.0 & 3:9 & 3.2 \\
\hline Goods and services & 5.0 & 5.1 & 5.4 & 6.4 & 7.1 \\
\hline Capital & 2.7 & 1.3 & 2.8 & 5.4 & 6.0 \\
\hline Operating balance & -5.7 & -8.0 & -7.9 & -2.1 & 1.7 \\
\hline Current account balance & 43.6 & 43.3 & 47.9 & 58.9 & 66.2 \\
\hline Overall balance & 40.9 & 42.0 & 45.1 & 53.5 & 60.2 \\
\hline \multicolumn{6}{|c|}{ (In percent of GDP) } \\
\hline Revenue & 3.4 & 3.4 & 3.4 & 3.6 & 3.6 \\
\hline Contributions & 1.9 & 2.0 & 2.0 & 2.1 & 2.0 \\
\hline Investment income & 1.3 & 1.3 & 1.4 & 1.4 & 1.4 \\
\hline Transfers from central government & 0.1 & 0.1 & 0.1 & 0.1 & 0.1 \\
\hline Expenditure & 2.2 & 2.2 & 2.2 & 2.3 & 2.1 \\
\hline Current & 2.1 & 2.2 & 2.2 & 2.1 & 2.0 \\
\hline Wages and salaries & 0.3 & 0.3 & 0.3 & 0.3 & 0.3 \\
\hline Benefit payments & 1.6 & 1.7 & 1.7 & 1.7 & 1.5 \\
\hline Goods and services & 0.1 & 0.1 & 0.1 & 0.1 & 0.1 \\
\hline Capital & 0.1 & 0.0 & 0.1 & 0.1 & 0.1 \\
\hline Operating balance & -0.2 & -0.2 & -0.2 & -0.1 & 0.0 \\
\hline Current account balance & 1.3 & 1.2 & 1.3 & 1.5 & 1.6 \\
\hline Overall balance & 1.2 & 1.2 & 1.2 & 1.4 & 1.5 \\
\hline \multicolumn{6}{|c|}{ (In percent, unless otherwise specified) } \\
\hline \multicolumn{6}{|l|}{ Memorandum items: } \\
\hline Benefits/contributions & 84.8 & 81.5 & 85.6 & 79.9 & 74.1 \\
\hline Wages, goods, and services/contributions & 23.8 & 23.1 & 24.3 & 20.2 & 21.4 \\
\hline Retirement and old-age payments/contributions & 46.2 & 45.8 & 45.1 & 41.3 & 41.5 \\
\hline Employment (actual numbers employed) & 507 & 510 & 513 & 523 & 517 \\
\hline
\end{tabular}

Source: National Insurance Board. 
Table 11. The Bahamas: National Insurance Board-Cash and Investments

(In millions of Bahamian dollars)

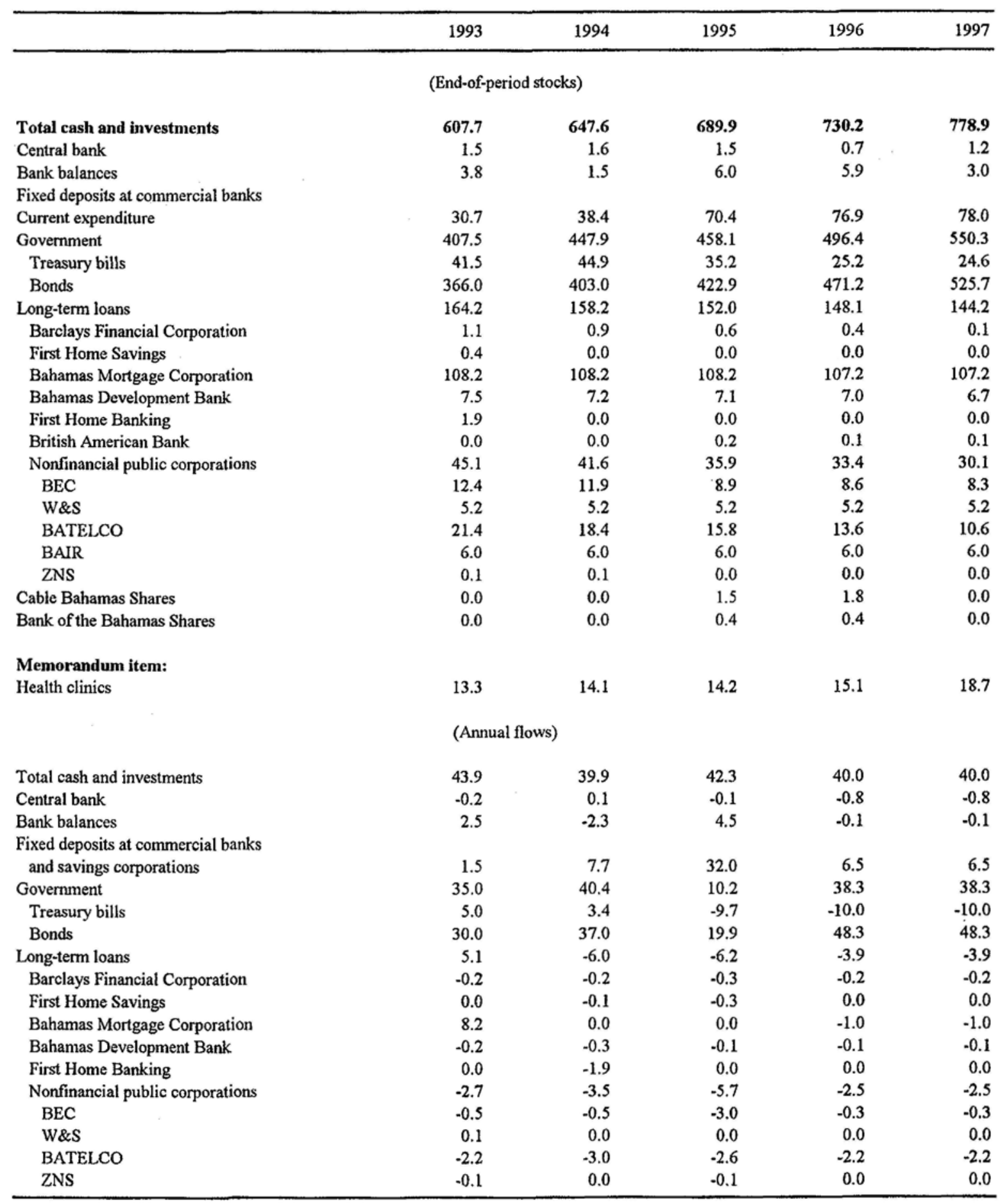

Source: National Insurance Board. 
Table 12. The Bahamas: Consolidated Operations of Nonfinancial Public Corporations

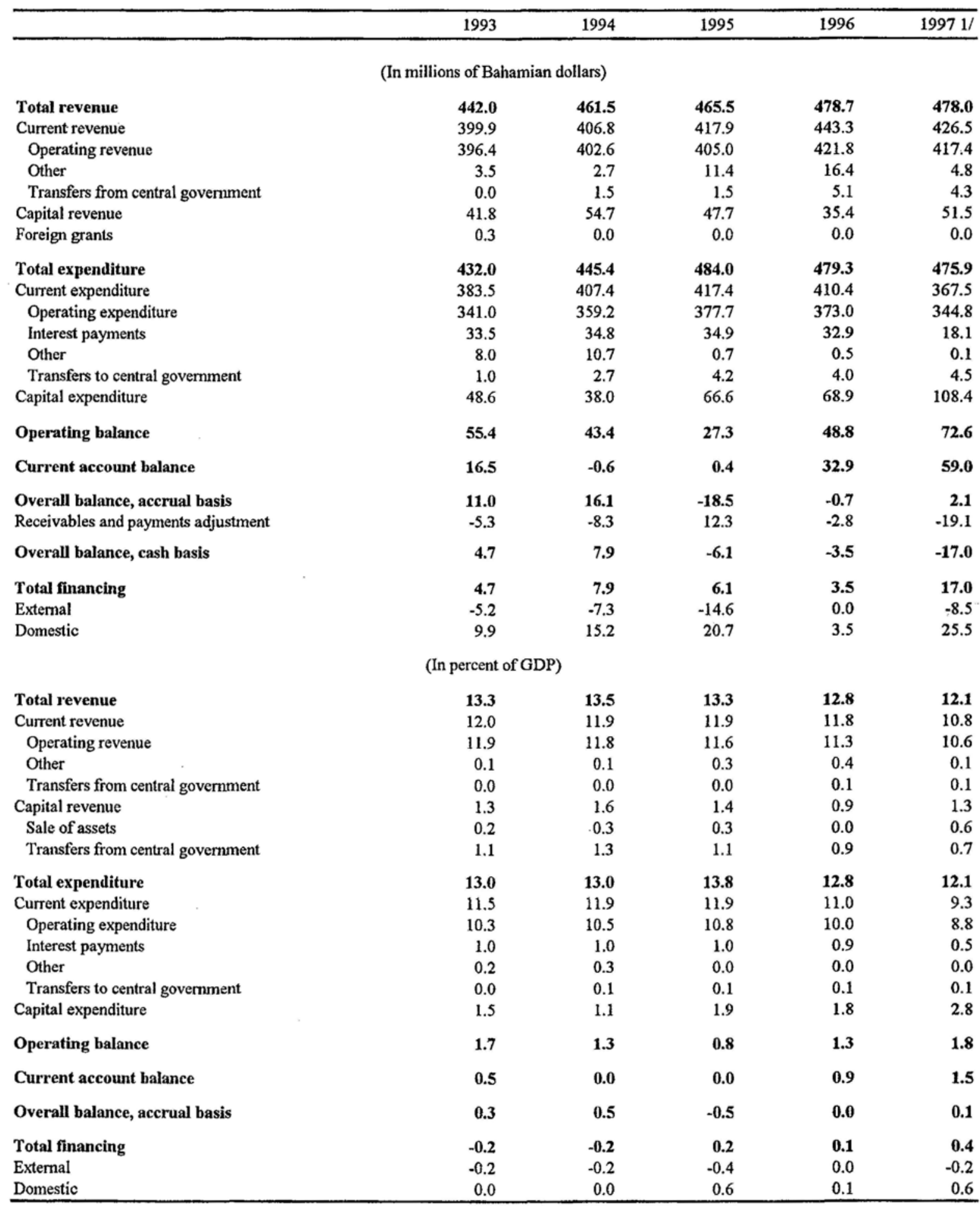

Sources: Ministry of Finance; public corporations; and Fund staff estimates. 
Table 13. The Bahamas: Operating Balances of Nonfinancial Public Corporations

\begin{tabular}{|c|c|c|c|c|c|}
\hline & 1994 & 1995 & 1996 & 1997 & 1998 \\
\hline \multicolumn{6}{|c|}{ (In millions of Bahamian dollars) } \\
\hline Total operational balance & 43.4 & 27.3 & 48.8 & $\ldots$ & $\ldots$ \\
\hline Bahamas Air Corporation & -1.8 & -1.9 & -2.6 & $\ldots$ & $\ldots$ \\
\hline Bahamas Telecommunications Corporation & 18.8 & 16.9 & 23.0 & 43.1 & 59.2 \\
\hline Bahamas Electricity Corporation & 34.5 & 27.9 & 33.5 & 31.3 & 41.7 \\
\hline Bahamas Broadcasting Corporation & -4.2 & -4.2 & -6.3 & -6.5 & -6.6 \\
\hline Bahamas Hotel Corporation & -2.8 & -8.2 & 0.9 & 3.8 & $\ldots$ \\
\hline Current expenditure & -1.0 & -3.1 & 0.3 & 0.9 & $\ldots$ \\
\hline Total overall balance, accrual basis & 16.1 & -18.5 & -0.7 & $\ldots$ & $\ldots$ \\
\hline Bahamas Air Corporation & 6.8 & 7.2 & 5.2 & $\ldots$ & $\ldots$ \\
\hline Bahamas Telecommunications Corporation & -3.7 & -16.6 & -8.6 & -1.9 & -5.6 \\
\hline Bahamas Electricity Corporation & 13.3 & 2.7 & 19.5 & -34.4 & -52.2 \\
\hline Bahamas Broadcasting Corporation & -1.9 & -1.9 & -1.2 & -1.1 & -0.9 \\
\hline Bahamas Hotel Corporation & 4.8 & -3.9 & -15.6 & 37.3 & $\ldots$ \\
\hline Bahamas Water and Sewerage Corporation & -3.2 & -6.0 & 0.0 & 2.2 & $\ldots$ \\
\hline
\end{tabular}

(In percent of GDP)

Total operational balance

Bahamas Air Corporation

Bahamas Telecommunications Corporation

Bahamas Electricity Corporation

Bahamas Broadcasting Corporation

Bahamas Hotel Corporation

Bahamas Water and Sewerage Corporation

Total overall balance, accrual basis

Bahamas Air Corporation

Bahamas Telecommunications Corporation

Bahamas Electricity Corporation

Bahamas Broadcasting Corporation

Bahamas Hotel Corporation

Bahamas Water and Sewerage Corporation

$\begin{array}{rrrrr}1.3 & 0.8 & \mathbf{1 . 3} & \ldots & \ldots \\ -0.1 & -0.1 & -0.1 & \ldots & \ldots \\ 0.5 & 0.5 & 0.6 & 1.1 & 1.4 \\ 1.0 & 0.8 & 0.9 & 0.8 & 1.0 \\ -0.1 & -0.1 & -0.2 & -0.2 & -0.2 \\ -0.1 & -0.2 & 0.0 & 0.1 & \ldots \\ 0.0 & -0.1 & 0.0 & 0.0 & \ldots\end{array}$

\begin{tabular}{rrrrr}
$\mathbf{0 . 5}$ & $-\mathbf{- 0 . 5}$ & $\mathbf{0 . 0}$ & $\ldots$ & $\ldots$ \\
0.2 & 0.2 & 0.1 & $\ldots$ & $\ldots$ \\
-0.1 & -0.5 & -0.2 & 0.0 & -0.1 \\
0.4 & 0.1 & 0.5 & -0.9 & -1.3 \\
-0.1 & -0.1 & 0.0 & 0.0 & 0.0 \\
0.1 & -0.1 & -0.4 & 0.9 & $\ldots$ \\
-0.1 & -0.2 & 0.0 & 0.1 & $\ldots$ \\
\hline
\end{tabular}

Sources: Ministry of Finance; public corporations; and Fund staff estimates. 
Table 14. The Bahamas: Summary Accounts of the Financial System

\begin{tabular}{llllll}
\hline & & & Prel. \\
& 1994 & 1995 & 1996 & 1997 & 1998 \\
\hline
\end{tabular}

(In millions of Bahamian dollars, end of period)

\begin{tabular}{|c|c|c|c|c|c|}
\hline Net foreign assets & -56.5 & -78.1 & -108.6 & -113.4 & -24.0 \\
\hline Central bank & 173.6 & 170.6 & 163.0 & 219.5 & 338.7 \\
\hline Commercial banks & -250.0 & -259.8 & -277.0 & -342.3 & -376.8 \\
\hline Other financial institutions & 19.9 & 11.1 & 5.4 & 9.5 & 14.1 \\
\hline Net domestic assets & $1,953.9$ & $2,090.1$ & $2,245.1$ & $2,488.8$ & $2,752.0$ \\
\hline Net credit to nonfinancial public sector & 424.8 & 409.5 & 408.7 & 392.3 & 429.8 \\
\hline Net claims on government & 412.5 & 424.1 & 422.1 & 420.2 & 452.6 \\
\hline In local currency & 374.0 & 392.7 & 397.6 & 395.5 & 433.4 \\
\hline Claims & 422.6 & 442.5 & 462.8 & 475.1 & 503.6 \\
\hline Deposits & -48.7 & -49.8 & -65.2 & -79.5 & -70.2 \\
\hline Net credit in foreign currency & 38.6 & 31.5 & 24.5 & 24.7 & 19.3 \\
\hline Deposits of the National Insurance Board & -39.0 & -70.9 & -77.6 & -82.0 & -109.3 \\
\hline Net claims on public corporations & 51.3 & 56.3 & 64.2 & 54.1 & 86.5 \\
\hline Net credit to financial public sector $1 /$ & -20.1 & -24.0 & -20.7 & -16.5 & -11.3 \\
\hline Credit to private sector & $1,859.0$ & $2,059.9$ & $2,264.0$ & $2,551.0$ & $2,918.6$ \\
\hline In local currency & $1,680.4$ & $1,881.0$ & $2,054.9$ & $2,287.5$ & $2,622.6$ \\
\hline In foreign currency & 178.6 & 178.9 & 209.1 & 263.5 & 296.0 \\
\hline Capital and surplus & -293.4 & -337.7 & -372.4 & -422.2 & -475.6 \\
\hline Net unclassified assets & -16.4 & -17.7 & -34.5 & -15.8 & -109.6 \\
\hline Liabilities to private sector & $\mathbf{1 , 8 9 7 . 3}$ & $2,012.0$ & $2,136.6$ & $2,375.4$ & $2,728.1$ \\
\hline Money & 386.2 & 401.9 & 415.9 & 484.7 & 565.9 \\
\hline Currency & 88.5 & 91.6 & 96.1 & 109.7 & 125.6 \\
\hline Demand deposits & 297.7 & 310.3 & 319.7 & 375.0 & 440.3 \\
\hline Savings and fixed deposits (local currency) & $1,487.2$ & $1,579.1$ & $1,696.8$ & $1,848.7$ & $2,106.5$ \\
\hline Foreign currency deposits & 23.9 & 31.0 & 23.9 & 42.1 & 55.7 \\
\hline
\end{tabular}

(Annual percentage change in terms of liabilities to the private sector at beginning of the period)

$\begin{array}{lrrrrr}\text { Net foreign assets } & 0.3 & -1.1 & -1.5 & -0.2 & 3.8 \\ \text { Net domestic assets } & 7.0 & 7.2 & 7.7 & 11.4 & 11.1 \\ \text { Credit to nonfinancial public sector } & -2.7 & -0.8 & 0.0 & -0.8 & 1.6 \\ \quad \text { Credit to central government } & -1.4 & 0.6 & -0.1 & -0.1 & 1.4 \\ \text { Credit to National Insurance Board } & -0.4 & -1.7 & -0.3 & -0.2 & -1.1 \\ \text { Credit to public corporations } & -0.9 & 0.3 & 0.4 & -0.5 & 1.4 \\ \text { Credit to financial public sector } & -0.3 & -0.2 & 0.2 & 0.2 & 0.2 \\ \text { Credit to private sector } & 10.8 & 10.6 & 10.1 & 13.4 & 15.5 \\ \text { Liabilities to private sector } & 7.3 & 6.0 & 6.2 & 11.2 & 14.8 \\ \text { Money } & 2.3 & 0.8 & 0.7 & 3.2 & 3.4 \\ \text { Quasi-money } & 4.9 & 5.2 & 5.5 & 8.0 & 11.4\end{array}$


Table 14. The Bahamas: Summary Accounts of the Financial System

\begin{tabular}{lcrrrr}
\hline & \multicolumn{1}{c}{} & & & Prel. \\
& \multicolumn{1}{c}{1994} & 1995 & 1996 & 1997 & 1998 \\
\hline & (Annual percentage changes) & & & \\
& & & & & \\
Net domestic assets & 6.7 & 7.0 & 7.4 & 10.9 & 10.6 \\
Credit to private sector & 11.5 & 10.8 & 9.9 & 12.7 & 14.4 \\
Liabilities to private sector & 7.3 & 6.0 & 6.2 & 11.2 & 14.8 \\
Money & 11.9 & 4.1 & 3.5 & 16.6 & 16.8 \\
Quasi-money & 6.1 & 6.5 & 6.9 & 9.9 & 14.4 \\
Memorandum item: & & & & & \\
Velocity (GDP/M2) & 1.8 & 1.7 & 1.8 & 1.7 & 1.5 \\
\hline
\end{tabular}

Sources: Central Bank of The Bahamas; and Fund staff estimates.

1/ Includes Bahamas Development Bank, Bahamas Mortgage Corporation and Bahamas Agricultural and Industrial Corporation. 
Table 15. The Bahamas: Accounts of the Central Bank

\begin{tabular}{|c|c|c|c|c|c|}
\hline & 1994 & 1995 & 1996 & 1997 & $\begin{array}{l}\text { Prel. } \\
1998 \\
\end{array}$ \\
\hline \multicolumn{6}{|c|}{ (In millions of Bahamian dollars) } \\
\hline Net official foreign assets & 173.6 & 170.6 & 163.0 & 219.5 & 338.7 \\
\hline Balances with banks abroad & 113.6 & 115.3 & 103.6 & 135.8 & 243.5 \\
\hline Foreign securities & 51.4 & 46.7 & 50.8 & 75.1 & 86.7 \\
\hline Reserve position in the Fund & 8.6 & 8.6 & 8.6 & 8.6 & 8.6 \\
\hline Net domestic assets & 65.8 & 77.4 & 79.3 & 42.5 & -26.3 \\
\hline Net credit to the nonfinancial public sector & 123.4 & 137.1 & 142.5 & 117.7 & 56.4 \\
\hline Net claims on government & 130.5 & 142.0 & 146.3 & 126.0 & 59.3 \\
\hline Claims & 143.7 & 149.1 & 153.2 & 141.2 & 61.9 \\
\hline Treasury bills & 64.8 & 73.7 & 80.3 & 80.4 & 0.0 \\
\hline Government bonds & 34.8 & 28.3 & 20.9 & 10.8 & 8.4 \\
\hline Loans and advances & 44.0 & 47.0 & 52.0 & 50.0 & 53.5 \\
\hline Deposits & -13.2 & -7.1 & -6.9 & -15.3 & -2.6 \\
\hline Deposits of the National Insurance Board & -0.6 & -0.5 & -0.7 & -1.2 & -1.6 \\
\hline Net claims on public corporations & -6.4 & -4.4 & -3.1 & -7.0 & -1.3 \\
\hline Net claims on financial public sector & 3.1 & 3.5 & 3.4 & 4.3 & 5.1 \\
\hline Credit to commercial banks & 0.0 & 0.0 & 0.0 & 0.3 & 0.3 \\
\hline Official capital and surplus & -76.1 & -78.2 & -79.8 & -83.9 & -86.9 \\
\hline Net unclassified assets & 15.4 & 15.0 & 13.2 & 4.1 & -1.2 \\
\hline Liabilities to commercial banks & 123.0 & 128.3 & 118.0 & 145.6 & 184.2 \\
\hline Notes and coins & 34.6 & 37.4 & 46.4 & 47.2 & 47.4 \\
\hline Deposits & 88.4 & 90.9 & 71.7 & 98.3 & 136.9 \\
\hline Liabilities to other financial institutions & 12.9 & 12.9 & 13.4 & -7.1 & -12.5 \\
\hline SDR allocation & 14.9 & 15.2 & 14.7 & 13.8 & 15.1 \\
\hline Currency held by the private sector & $\mathbf{8 8 . 5}$ & 91.6 & 96.1 & 109.7 & 125.6 \\
\hline
\end{tabular}

(Annual percentage changes in terms of reserve money at the beginning of the period)

Net international reserves

Net domestic assets

Net credit to nonfinancial public sector

Central government

Net credit to banks

Liabilities to commercial banks

Liabilities to other financial institutions

Currency held by the private sector

$\begin{array}{rrrrr}4.6 & -1.3 & -3.3 & 24.8 & 48.1 \\ 7.8 & 5.2 & 0.8 & -16.2 & -27.7 \\ 16.8 & 11.1 & 2.3 & -10.9 & -24.7 \\ 8.7 & 5.1 & 1.8 & -8.9 & -52.9 \\ 0.0 & 0.0 & 0.0 & 0.1 & 0.0 \\ & & & & \\ 9.1 & 2.4 & -4.4 & 12.1 & 15.6 \\ 0.0 & 0.0 & 0.2 & -9.0 & -2.2 \\ 2.9 & 1.4 & 2.0 & 6.0 & 6.4\end{array}$


Table 15. The Bahamas: Accounts of the Central Bank

\begin{tabular}{|c|c|c|c|c|c|}
\hline & 1994 & 1995 & 1996 & 1997 & $\begin{array}{l}\text { Prel. } \\
1998 \\
\end{array}$ \\
\hline \multicolumn{6}{|c|}{ (Annual percentage changes) } \\
\hline Net domestic assets & 31.0 & 17.7 & 2.5 & -46.5 & -161.9 \\
\hline $\begin{array}{l}\text { Net credit to the nonfinancial public sector } \\
\text { Of which: }\end{array}$ & 16.8 & 11.1 & 3.9 & -17.4 & -52.0 \\
\hline Central government & 15.5 & 8.8 & 3.0 & -13.9 & -52.9 \\
\hline Reserve money & 12.0 & 3.7 & -2.2 & 9.0 & 19.8 \\
\hline Currency in circulation & 10.0 & 4.8 & 10.5 & 10.1 & 10.2 \\
\hline \multicolumn{6}{|c|}{ (In millions of Bahamian dollars; unless otherwise indicated) } \\
\hline \multicolumn{6}{|l|}{ Memorandum items: } \\
\hline Reserve money & 224.4 & 232.8 & 227.6 & 248.2 & 297.4 \\
\hline Currency in circulation & 123.1 & 129.0 & 142.5 & 156.9 & 173.0 \\
\hline Change in net international reserves & 9.3 & -3.0 & -7.6 & 56.5 & 119.2 \\
\hline $\mathrm{NIR} /$ reserve money (in percent) & 77.4 & 73.3 & 71.6 & 88.4 & 113.9 \\
\hline Currency held by the private sector/GDP & 2.6 & 2.6 & 2.6 & 2.8 & 3.0 \\
\hline
\end{tabular}

Sources: Central Bank of the Bahamas; and Fund staff estimates. 
Table 16. The Bahamas: Accounts of the Commercial Banks

(In millions of Bahamian dollars)

\begin{tabular}{|c|c|c|c|c|c|}
\hline & 1994 & 1995 & 1996 & 1997 & $\begin{array}{l}\text { Prel. } \\
1998 \\
\end{array}$ \\
\hline Net foreign assets & -250.0 & -259.8 & -277.0 & -342.3 & -376.8 \\
\hline Net claims on central bank & 123.0 & 128.3 & 118.0 & 145.3 & 183.9 \\
\hline Notes and coins & 34.6 & 37.4 & 46.4 & 47.2 & 47.4 \\
\hline Balances & 88.4 & 90.9 & 71.7 & 98.3 & 136.9 \\
\hline Central bank advances & 0.0 & 0.0 & 0.0 & -0.3 & -0.3 \\
\hline Net domestic assets & $1,677.6$ & $1,793.4$ & $1,928.0$ & $2,420.7$ & $2,749.7$ \\
\hline Net claims on government & 260.0 & 259.8 & 254.1 & 291.2 & 390.1 \\
\hline Treasury bills & 13.6 & 13.4 & 25.9 & 23.8 & 95.5 \\
\hline Other securities & 197.5 & 208.4 & 202.0 & 247.6 & 290.2 \\
\hline Loans and advances & 84.6 & 81.4 & 85.3 & 84.8 & 72.7 \\
\hline In local currency & 45.8 & 49.3 & 59.9 & 59.4 & 52.8 \\
\hline In foreign currency & 38.8 & 32.1 & 25.3 & 25.5 & 19.9 \\
\hline Deposits & -35.7 & -43.3 & -59.1 & -65.0 & -68.3 \\
\hline In local currency & -35.5 & -42.7 & -58.3 & -64.2 & -67.7 \\
\hline In foreign currency & -0.3 & -0.6 & -0.8 & -0.8 & -0.6 \\
\hline Deposits of the National Insurance Board & -38.2 & -70.2 & -72.7 & -80.6 & -107.4 \\
\hline Net claims on public corporations & 58.6 & 61.2 & 67.5 & 60.9 & 87.3 \\
\hline Net claims on financial public sector $1 /$ & -23.2 & -27.5 & -24.1 & -20.8 & -16.4 \\
\hline Net claims on other financial institutions & -13.8 & -19.6 & -30.1 & -18.8 & -17.8 \\
\hline Credit to private sector & $1,591.6$ & $1,777.3$ & $1,966.6$ & $2,488.2$ & $2,767.3$ \\
\hline Private capital and surplus & -135.2 & -160.9 & -189.6 & -281.3 & -328.4 \\
\hline Net unciassified assets & -22.1 & -26.7 & -43.7 & -18.1 & -25.0 \\
\hline Liabilities to private sector & $1,550.6$ & $1,662.0$ & $1,769.1$ & $2,223.6$ & $2,556.8$ \\
\hline Demand deposits & 300.4 & 314.7 & 325.5 & 395.7 & 476.6 \\
\hline In local currency & 289.4 & 299.3 & 308.0 & 371.5 & 435.8 \\
\hline In foreign currency & 11.1 & 15.4 & 17.5 & 24.3 & 40.8 \\
\hline Savings deposits & 274.5 & 279.2 & 291.3 & 391.9 & 435.7 \\
\hline In local currency & 273.6 & 277.6 & 290.8 & 390.1 & 435.5 \\
\hline In foreign currency & 0.9 & 1.6 & 0.5 & 1.9 & 0.2 \\
\hline Fixed deposits & 975.7 & $1,068.1$ & $1,152.3$ & $1,435.9$ & $1,644.5$ \\
\hline In local currency & 963.7 & $1,054.1$ & $1,146.4$ & $1,420.0$ & $1,629.8$ \\
\hline In foreign currency & 12.0 & 14.0 & 5.9 & 15.9 & 14.7 \\
\hline
\end{tabular}

Source: Central Bank of The Bahamas.

1/ Includes Bahamas Development Bank, Bahamas Mortgage Corporation and Bahamas Agricultural and Industrial Corporation. 
Table 17. The Bahamas: Accounts of Other Local Financial Institutions 1/

(In millions of Bahamian dollars)

\begin{tabular}{|c|c|c|c|c|c|}
\hline & 1994 & 1995 & 1996 & 1997 & $\begin{array}{r}\text { Prel. } \\
1998 \\
\end{array}$ \\
\hline Net foreign assets & 19.9 & 11.1 & 5.4 & 9.5 & 14.1 \\
\hline Net claims on central bank & 12.9 & 12.9 & 13.4 & -7.1 & -12.5 \\
\hline Notes and coins & 0.7 & 0.8 & 0.8 & 0.3 & 0.3 \\
\hline Balances & 12.1 & 12.1 & 12.6 & -7.4 & -12.8 \\
\hline Net domestic assets & 224.4 & 234.4 & 252.5 & 39.7 & 44.1 \\
\hline Net claims on government & 22.1 & 22.3 & 21.8 & 3.1 & 3.2 \\
\hline Deposits of the National Iinsurance Board & -0.2 & -0.2 & -4.2 & -0.3 & -0.3 \\
\hline Net claims on public corporations & -0.8 & -0.6 & -0.3 & 0.2 & 0.5 \\
\hline Net claims on financial public sector $2 /$ & 0.0 & 0.0 & 0.0 & 0.0 & 0.0 \\
\hline Net claims on commercial banks & 13.8 & 19.6 & 30.1 & 18.8 & 16.8 \\
\hline Credit to private sector & 267.4 & 282.6 & 297.4 & 62.8 & 69.4 \\
\hline Mortgages & 231.7 & 239.3 & 247.1 & 51.8 & 56.6 \\
\hline Other & 35.8 & 43.3 & 50.3 & 11.1 & 12.8 \\
\hline Private capital and surplus & -82.1 & -98.6 & -102.9 & -57.0 & -60.2 \\
\hline Net unclassified assets & 4.2 & 9.2 & 10.7 & 12.1 & 14.7 \\
\hline Liabilities to the private sector & 257.2 & 258.4 & 271.3 & 42.1 & 45.6 \\
\hline Demand deposits & 8.3 & 11.0 & 11.7 & 3.5 & 4.5 \\
\hline Saving deposits & 64.7 & 64.3 & 64.2 & 2.7 & 1.8 \\
\hline Fixed deposits & 185.2 & 183.0 & 195.4 & 35.9 & 39.4 \\
\hline
\end{tabular}

Source: Central Bank of The Bahamas.

1/ Includes savings and loan institutions and finance and trust companies domiciled in The Bahamas.

2/ Includes Bahamas Development Bank, Bahamas Mortgage Corporation, and Bahamas Agricultural and Industrial Corporation. 
Table 18. The Bahamas: Loans and Advances of Commercial Banks 1/

\begin{tabular}{|c|c|c|c|c|c|}
\hline & 1994 & 1995 & 1996 & 1997 & $\begin{array}{l}\text { Prel. } \\
1998 \\
\end{array}$ \\
\hline \multicolumn{6}{|c|}{ (In millions of Bahamian dollars) } \\
\hline Total & $1,705.6$ & $\mathbf{1 , 8 5 7 . 0}$ & $2,035.0$ & $2,565.7$ & $2,894.7$ \\
\hline Foreign currency & 227.0 & 218.8 & 239.8 & 316.6 & 383.5 \\
\hline Domestic currency & $1,478.6$ & $1,638.2$ & $1,795.1$ & $2,249.1$ & $2,511.2$ \\
\hline Hotels, restaurants, and night clubs & 136.6 & 153.3 & $\mathbf{1 5 7 . 4}$ & 166.8 & 217.3 \\
\hline Foreign currency & 82.8 & 90.9 & 100.2 & 120.5 & 161.9 \\
\hline Domestic currency & 53.8 & 62.4 & 57.2 & 46.3 & 55.4 \\
\hline Trade and commerce & 175.3 & 195.3 & 200.4 & 202.4 & $\mathbf{1 9 7 . 7}$ \\
\hline Foreign currency & 17.1 & 22.8 & 23.1 & 35.6 & 25.0 \\
\hline Domestic currency & 158.2 & 172.5 & 177.4 & 166.8 & 172.7 \\
\hline Building, construction, and real estate & 117.1 & 108.4 & 124.7 & 159.6 & $\mathbf{1 5 5 . 8}$ \\
\hline Foreign currency & 16.9 & 18.1 & 25.0 & 32.0 & 38.8 \\
\hline Domestic currency & 100.3 & 90.4 & 99.7 & 127.6 & 117.0 \\
\hline Manufacturing and quarrying & $\mathbf{5 5 . 5}$ & 52.3 & 60.2 & 66.1 & 78.0 \\
\hline Foreign currency & 22.4 & 16.2 & 22.8 & 32.8 & 36.8 \\
\hline Domestic currency & 33.1 & 36.1 & 37.4 & 33.3 & 41.2 \\
\hline Agriculture and fisheries & 18.4 & 24.5 & 24.2 & 25.9 & 27.8 \\
\hline Foreign currency & 2.0 & 4.3 & 1.8 & 4.1 & 2.5 \\
\hline Domestic currency & 16.4 & 20.2 & 22.4 & 21.7 & 25.3 \\
\hline $\begin{array}{l}\text { Personal and other loans } \\
\text { Of which }\end{array}$ & $1,129.8$ & $1,246.1$ & $1,386.0$ & $1,865.8$ & $2,090.4$ \\
\hline Consumer credit & 288.0 & 579.7 & 761.5 & 981.2 & $1,136.4$ \\
\hline Foreign currency & 37.6 & 26.8 & 22.4 & 38.1 & 32.8 \\
\hline Domestic currency & $1,092.2$ & $1,219.3$ & $1,363.6$ & $1,827.7$ & $2,057.6$ \\
\hline Public corporations & 72.8 & 77.1 & 82.1 & 79.1 & 127.6 \\
\hline Foreign currency & 48.2 & 39.7 & 44.7 & 53.5 & 85.7 \\
\hline Domestic currency & 24.7 & 37.4 & 37.4 & 25.6 & 41.9 \\
\hline \multicolumn{6}{|c|}{ (In percent of total loans and advances) } \\
\hline Loans in foreign currency & 13.3 & 11.8 & 11.8 & 12.3 & 13.2 \\
\hline Loans in local currency & 86.7 & 88.2 & 88.2 & 87.7 & 86.8 \\
\hline Personal loans & 66.2 & 67.1 & 68.1 & 72.7 & 72.2 \\
\hline \multicolumn{6}{|l|}{ Of which } \\
\hline Consumer credit & 16.9 & 31.2 & 37.4 & 38.2 & 39.3 \\
\hline
\end{tabular}

Source: Central Bank of The Bahamas.

1/ Excluding unearned interest and loans and advances to the government. 
Table 19. The Bahamas: Commercial Banks' Reserve Position

\begin{tabular}{rrrrrrr}
\hline Total & Required & Excess & Net Free & Total & Excess & Net Free \\
Reserves 1/ & Reserves & Reserves & Reserves 2/ & Reserves & Reserves & Reserves \\
\hline
\end{tabular}

(In millions of Bahamian dollars, at end of period)

(In percent ) 3/

1994

$\begin{array}{lll}\text { I } & 121.9 & 75.5\end{array}$

$\begin{array}{lll}\text { II } & 133.3 & 77.8\end{array}$

III $\quad 114.1 \quad 79.1$

$\begin{array}{lll}\text { IV } & 106.7 & \mathbf{8 0 . 8}\end{array}$

$35: 0$

25.9

46.4

55.5

46.4

55.5

35.0

25.9

29.2

29.2

26.2

84.8

26.2

22.6

22.6

26.4

7.8
8.4
7.2
6.5

3.0

3.0

1995

II

109.0

86.4
87.6

26.4

6.6

1.7

3.5

3.5

IV

114.0

87.6

6.2

2.2

2.2

6.5

1.6

1.6

1996

II

123.2

88.8

34.4

90.3

25.1

34.4

25.1

20.5

20.5

26.3

26.3

6.4

1.5

1.7

III

113.6

93.6

6.9

1.9

1.9

1997

II

122.0

97.6

24.5

35.4

24.5

6.3

1.4

1.4

III

148.5

113.1

29.4

35.4

115.1

28.6

6.1

1.1

6.4

1.1

IV

147.8

116.5

31.3

31.0

5.6

6.6

1.1

1.1

6.2

1.6

1.6

6.3

1.3

1.2

1998

I

II

149.0

118.7

30.4

30.1

6.0

1.3

1.3

III

180.8

130.8

50.0

49.7

53.0

52.7

130.0

42.0

41.7

7.0

1.2

1.2

175.1

133.2

6.9

1.9

1.9

6.4

2.0

2.0

Source: Central Bank of The Bahamas.

1/ Currency holdings plus balances with the central bank.

2/ Excess reserves minus borrowing from the central bank.

3/ Percent of total resident dollar deposit liabilities of private sector and public corporations. 
Table 20. The Bahamas: Liquidity Position of Commercial Banks

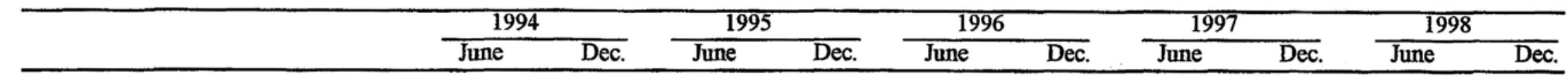

(In millions of Bahamian dollars, at end of month)

\begin{tabular}{|c|c|c|c|c|c|c|c|c|c|c|}
\hline Currency holdings & 24.3 & 34.8 & 22.3 & 37.7 & 26.0 & 46.6 & 30.9 & 47.5 & 38.0 & 47.6 \\
\hline Net balance with the Central Bank & 100.1 & 88.4 & 93.1 & 90.9 & 89.7 & 71.7 & 123.1 & $98: 3$ & 157.0 & 135.5 \\
\hline Treasury bills & 48.7 & 13.6 & 17.0 & 13.4 & 55.6 & 25.9 & 107.7 & 23.8 & 90.9 & 95.5 \\
\hline Other government securities & 197.6 & 193.3 & 202.5 & 179.2 & 185.9 & 172.8 & 211.4 & 218.2 & 220.0 & 261.0 \\
\hline $\begin{array}{l}\text { Net balance with other financial } \\
\text { institutions }\end{array}$ & -12.7 & -11.2 & -25.6 & -8.5 & -4.9 & -8.2 & -12.8 & -8.1 & -7.5 & -11.1 \\
\hline Total eligible liquid assets & 372.7 & 333.6 & 323.5 & 325.5 & 362.2 & 318.3 & 482.3 & 400.7 & 517.2 & 545.4 \\
\hline Required liquid assets $1 /$ & 257.2 & 266.3 & 278.2 & 290.1 & 303.1 & 311.9 & 371.2 & 383.5 & 418.6 & 441.9 \\
\hline Excess liquid assets & 115.5 & 67.3 & 45.3 & 35.4 & 59.1 & 6.5 & 111.1 & 17.1 & 98.6 & 103.4 \\
\hline \multicolumn{11}{|c|}{ (In percent of Bahamian dollar deposit liabilities) } \\
\hline Excess liquid assets & 7.4 & 4.2 & 2.7 & 2.0 & 3.2 & 0.3 & 4.8 & 0.7 & 3.7 & 3.7 \\
\hline
\end{tabular}

Source: Central Bank of The Bahamas.

1 / Sum of 20 percent of demand deposits, and 15 percent of time and savings deposits (including time deposits placed by the central bank). 
Table 21. The Bahamas: Selected Interest Rates 1/

(Average of ranges, in percent per annum)

\begin{tabular}{|c|c|c|c|c|c|c|c|c|c|c|c|}
\hline & \multirow[b]{2}{*}{1994} & \multirow[b]{2}{*}{1995} & \multirow[b]{2}{*}{1996} & \multicolumn{3}{|c|}{1997} & \multirow[b]{2}{*}{$\overline{\text { IV }}$} & \multicolumn{4}{|c|}{1998} \\
\hline & & & & $\bar{I}$ & II & III & & $\mathrm{I}$ & II & III & $\overline{\text { IV }}$ \\
\hline \multicolumn{12}{|l|}{$\begin{array}{l}\text { Commercial bank interest rates } \\
\text { Deposit rates }\end{array}$} \\
\hline $\begin{array}{l}\text { Savings deposits } \\
\text { Fixed deposits }\end{array}$ & 4.0 & 3.7 & 3.6 & 3.2 & 3.2 & 3.5 & 3.7 & 3.3 & 3.6 & 2.9 & 2.8 \\
\hline Up to 3 months & 4.4 & 4.3 & 3.3 & 5.3 & 5.3 & 5.2 & 5.3 & 5.7 & 5.8 & 5.4 & 5.4 \\
\hline Up to 6 months & 4.4 & 4.8 & 5.1 & 5.9 & 6.0 & 5.7 & 6.0 & 6.3 & 6.3 & 6.0 & 5.6 \\
\hline Up.to 12 months & 4.5 & 5.0 & 6.0 & 5.7 & 5.6 & 5.4 & 5.8 & 6.0 & 6.1 & 5.8 & 5.7 \\
\hline Over 12 months & 4.6 & 5.1 & 5.5 & 5.1 & 5.2 & 5.1 & 5.7 & 5.8 & 6.4 & 5.9 & 5.7 \\
\hline Weighted average rate on deposits & 4.4 & 4.2 & 5.1 & 5.4 & 5.3 & 5.2 & 5.4 & 5.7 & 5.8 & 5.4 & 5.3 \\
\hline \multicolumn{12}{|l|}{ Lending rates $2 /$} \\
\hline $\begin{array}{l}\text { Prime lending rate } \\
\text { Mortgage loan rates } 3 /\end{array}$ & 6.8 & 6.8 & 6.8 & 6.8 & 6.8 & 6.8 & 6.8 & 6.8 & 6.8 & 6.8 & 6.8 \\
\hline Residential & 11.0 & 11.2 & 10.1 & 10.1 & 10.1 & 10.1 & 10.0 & 9.9 & 10.0 & 9.8 & 9.9 \\
\hline Commercial & 11.0 & 11.3 & 11.0 & 10.6 & 10.6 & 10.3 & 11.0 & 9.8 & 10.7 & 10.1 & 9.9 \\
\hline Consumer loans & 16.2 & 14.1 & 14.7 & 14.7 & 14.9 & 14.7 & 14.6 & 14.4 & 14.9 & 14.6 & 14.3 \\
\hline Weighted average rate on loans & 14.2 & 13.4 & 12.6 & 12.3 & 12.7 & 13.1 & 12.9 & 12.4 & 12.7 & 12.0 & 12.2 \\
\hline \multicolumn{12}{|l|}{ Other interest rates } \\
\hline Treasury bill rate & 2.0 & 4.6 & 4.4 & 4.3 & 4.4 & 4.2 & 4.5 & 4.3 & 4.2 & 3.7 & 3.2 \\
\hline Central bank rediscount rate $4 /$ & 2.5 & 5.1 & 4.9 & 4.8 & 4.9 & 4.7 & 5.0 & 4.6 & 4.7 & 4.2 & 3.7 \\
\hline Bank rate $5 /$ & 6.5 & 6.5 & 6.5 & 6.5 & 6.5 & 6.5 & 6.5 & 6.5 & 6.5 & 6.5 & 6.5 \\
\hline \\
\hline $\begin{array}{l}\text { LIBOR on 3-month U.S. dollar } \\
\text { deposits }\end{array}$ & 47 & 60 & 54 & 55 & 57 & 57 & 58 & 56 & 56 & 56 & 52 \\
\hline U.S. Treasury bill rate & 43 & 55 & 50 & 51 & 51 & 51 & 50 & 51 & 50 & 40 & 43 \\
\hline U.s. Heasury oil tate & 4.5 & 3.5 & 3.0 & 3.1 & $J .1$ & 0.1 & 3.0 & 3.1 & 3.0 & 4.9 & 4.5 \\
\hline
\end{tabular}

Sources: Central Bank of The Bahamas; and International Financial Statistics.

1/ On instruments denominated in Bahamian dollars; rates are averages of the quarters..

2/ Rates represent midpoint of the ranges reported by the central bank.

3/ Offered by other local financial institutions, except for commercial mortgage rates after 1994, which are rates offered by commercial banks.

4/ The rate at which the central bank discounts treasury bills.

5/ The rate at which the central bank makes advances to commercial banks, end of period. 
Table 22. The Bahamas: Balance of Payments

(In millions of U.S. dollars)

\begin{tabular}{|c|c|c|c|c|c|}
\hline & 1994 & 1995 & 1996 & 1997 & $\begin{array}{l}\text { Prel. } \\
1998 \\
\end{array}$ \\
\hline Current account & -41.7 & -143.2 & -271.1 & -658.1 & -943.1 \\
\hline Trade balance & -815.1 & -930.2 & $-1,022.8$ & $-1,300.1$ & $-1,373.1$ \\
\hline Exports & 198.5 & 226.3 & 249.7 & 246.2 & 362.9 \\
\hline Imports & $1,013.6$ & $1,156.6$ & $1,272.5$ & $1,546.3$ & $1,736.0$ \\
\hline Services, net & 883.8 & 905.0 & 863.5 & 751.3 & 586.2 \\
\hline Transportation, net & -64.9 & -81.7 & -114.3 & -134.8 & -146.8 \\
\hline Travel, net & $1,134.1$ & $1,133.1$ & $1,163.3$ & $1,166.1$ & $1,152.2$ \\
\hline Insurance & -72.0 & -74.3 & -72.1 & -65.5 & -59.7 \\
\hline Construction services & -64.8 & -12.3 & -20.4 & -75.1 & -145.8 \\
\hline Royalty and license fees & -5.1 & -4.6 & -6.5 & -9.5 & -9.1 \\
\hline Offshore Co. Loc. Exp & 107.8 & 117.5 & 110.0 & 94.9 & 85.2 \\
\hline Other services, net & -137.4 & -158.8 & -169.6 & -198.9 & -253.7 \\
\hline Government services & -13.9 & -13.9 & -26.9 & -25.9 & -36.1 \\
\hline Income & -137.6 & -135.9 & -149.0 & -148.5 & -190.6 \\
\hline Labor income & -25.0 & -27.8 & -29.1 & -31.1 & -34.5 \\
\hline Interest and dividends, net & -112.6 & -108.1 & -119.9 & -117.4 & -156.1 \\
\hline Official transactions & -4.0 & 1.2 & -5.9 & -4.2 & 0.0 \\
\hline Central bank investment income & 3.2 & 9.1 & 10.6 & 8.6 & 5.7 \\
\hline Interest on government transactions & -7.2 & -7.9 & -16.5 & -12.8 & -5.7 \\
\hline Private transactions & -108.6 & -109.3 & -114.0 & -113.2 & -156.1 \\
\hline Commercial banks and trusts & -16.3 & -15.8 & -19.1 & -22.3 & -26.9 \\
\hline Other private & -92.3 & -93.5 & -94.9 & -94.9 & -129.2 \\
\hline Current transfers, net & 27.2 & 17.9 & 37.2 & 39.3 & 34.4 \\
\hline Government & 29.0 & 20.7 & 40.1 & 43.7 & 38.1 \\
\hline Private & -1.8 & -2.8 & -2.9 & -4.4 & -3.7 \\
\hline Capital account & 57.3 & 88.5 & 156.9 & 402.8 & 724.4 \\
\hline Capital transfers & -11.6 & -12.5 & -24.4 & -13.0 & -11.7 \\
\hline Direct investment & 23.5 & 106.6 & 88.2 & 209.5 & 339.0 \\
\hline Property purchases, net & -18.3 & 20.8 & 9.6 & 14.7 & 8.6 \\
\hline Equity, net & 41.8 & 85.8 & 78.6 & 194.8 & 330.4 \\
\hline Long -term public sector & -19.5 & -29.2 & -25.2 & 23.1 & -11.0 \\
\hline Government, net & -5.7 & -9.7 & -18.2 & 13.8 & -13.3 \\
\hline Nonfinancial public corporations & -15.7 & -17.4 & -7.0 & 9.3 & 2.3 \\
\hline Domestic banks & 3.7 & 12.2 & 23.0 & 61.2 & 29.9 \\
\hline Other private capital, net & 61.2 & 11.4 & 95.3 & 122.0 & 378.2 \\
\hline Net errors and omissions & -6.3 & 51.8 & 106.6 & 311.8 & 338.0 \\
\hline Overall balance & 9.3 & -2.9 & -7.6 & 56.5 & 119.3 \\
\hline Change in net international reserves (increase -) & -9.3 & 2.9 & 7.6 & -56.5 & -119.3 \\
\hline
\end{tabular}

Sources: Central Bank of the Bahamas, and Fund staff estimates. 
Table 23. The Bahamas: Composition of Merchandise Exports

(In millions of dollars)

\begin{tabular}{|c|c|c|c|c|c|}
\hline & 1994 & 1995 & 1996 & 1997 & $\begin{array}{l}\text { Prel. } \\
1998 \\
\end{array}$ \\
\hline Total exports & 198.5 & 226.3 & 249.7 & 246.2 & 362.9 \\
\hline Total merchandise exports & 163.7 & 176.9 & 174.2 & 181.4 & 300.3 \\
\hline Primary goods & 108.1 & 100.5 & 107.9 & 106.0 & 112.4 \\
\hline Food and live animals & 62.8 & 65.8 & 70.8 & 66.2 & 76.6 \\
\hline Beverage and tobacco & 9.0 & 3.5 & 4.9 & 5.5 & 13.0 \\
\hline Other animal and vegetable products & 0.0 & 0.0 & 0.0 & 0.0 & 0.2 \\
\hline Nonedible raw materials excluding fuel & 33.0 & 31.2 & 32.2 & 34.3 & 22.6 \\
\hline Fuel and lubricants & 3.3 & 0.0 & 0.0 & 0.0 & 0.0 \\
\hline Manufactured goods & 32.9 & 30.4 & 32.9 & 44.9 & 109.6 \\
\hline Chemical products & 22.0 & 16.8 & 17.3 & 34.2 & 42.5 \\
\hline $\begin{array}{l}\text { Other manufactured goods, excluding } \\
\text { capital goods }\end{array}$ & 10.9 & 13.6 & 15.6 & 10.7 & 67.1 \\
\hline Capital goods & 22.7 & 46.0 & 33.4 & 30.5 & 78.3 \\
\hline Goods procured in port by carriers & 34.8 & 49.4 & 75.5 & 64.8 & 62.6 \\
\hline
\end{tabular}

Sources: Department of Statistics; and Central Bank of the Bahamas. 
Table 24. The Bahamas: Composition of Merchandise Imports

(In millions of dollars)

\begin{tabular}{|c|c|c|c|c|c|}
\hline & 1994 & 1995 & 1996 & 1997 & $\begin{array}{l}\text { Prel. } \\
1998 \\
\end{array}$ \\
\hline Total imports & $1,013.6$ & $1,156.6$ & $1,272.5$ & $1,546.3$ & $1,736.0$ \\
\hline Primary goods & 356.1 & 395.2 & 448.1 & 467.1 & 454.9 \\
\hline Food and live animals & 180.9 & 192.1 & 206.1 & 213.9 & 202.2 \\
\hline Beverage and tobacco & 18.0 & 18.7 & 18.9 & 25.0 & 45.0 \\
\hline Other animal and vegetable products & 3.2 & 3.5 & 3.6 & 3.3 & 3.1 \\
\hline Nonedible raw materials excluding fuel & 21.1 & 24.1 & 25.1 & 32.7 & 34.9 \\
\hline Fuel and lubricants & 132.9 & 156.8 & 194.4 & 192.2 & 169.6 \\
\hline Manufactured goods & 431.5 & 477.8 & 512.4 & 651.0 & 772.0 \\
\hline Chemical products & 83.0 & 93.6 & 116.3 & 153.9 & 237.4 \\
\hline $\begin{array}{l}\text { Other manufactured goods } \\
\text { (excluding capital goods) }\end{array}$ & 348.5 & 384.1 & 396.1 & 497.1 & 534.6 \\
\hline Capital goods & 226.0 & 283.6 & 311.9 & 428.3 & 509.1 \\
\hline
\end{tabular}

Source: Department of Statistics and Central Bank. 
Table 25. The Bahamas: Public External Debt and Debt Service

\begin{tabular}{|c|c|c|c|c|c|}
\hline & 1994 & 1995 & 1996 & 1997 & $\begin{array}{l}\text { Prel. } \\
1998 \\
\end{array}$ \\
\hline \multicolumn{6}{|c|}{ (In millions of U.S. dollars) } \\
\hline External debt outstanding & 336.7 & 308.5 & 290.2 & 388.3 & 348.7 \\
\hline Multilateral creditors & 167.9 & 170.5 & 177.9 & 177.3 & 166.7 \\
\hline Official bilateral & 43.6 & 40 & 36.4 & 30.8 & 27.2 \\
\hline Commercial creditors & 97.4 & 72.8 & 54.8 & 122.9 & 97.9 \\
\hline Other & 27.8 & 25.2 & 21.1 & 7.3 & 6.9 \\
\hline Debt service & 69.3 & 67.3 & 61.8 & 81.8 & 67.3 \\
\hline Multilateral creditors & 20.9 & 28.1 & 26.3 & 26.3 & 24.2 \\
\hline Official bilateral & 7.6 & 7.3 & 5.2 & 18.4 & 8 \\
\hline Commercial creditors & 37.3 & 29.5 & 28.4 & 34.4 & 30.8 \\
\hline Other & 3.5 & 2.5 & 1.9 & 2.7 & 4.3 \\
\hline Amortization & 43.7 & 42.3 & 40.2 & 54.7 & 44.7 \\
\hline Multilateral creditors & 6 & 13.7 & 13.5 & 13.8 & 15.6 \\
\hline Official bilateral & 3.7 & 3.6 & 3.6 & 13.2 & 3.6 \\
\hline Commercial creditors & 32 & 24.6 & 23.1 & 27.5 & 25 \\
\hline Other & 1.9 & 0.4 & 0 & 0.2 & 0.4 \\
\hline Interest & 25.7 & 25 & 21.6 & 27.2 & 22.7 \\
\hline Multilateral creditors & 14.9 & 14.3 & 12.8 & 12.5 & 8.6 \\
\hline Official bilateral & 3.9 & 3.6 & 1.6 & 5.2 & 4.4 \\
\hline Commercial creditors & 5.3 & 4.9 & 5.3 & 6.9 & 5.8 \\
\hline Other & 1.5 & 2.1 & 1.9 & 2.5 & 3.9 \\
\hline \multicolumn{6}{|c|}{ (In percent of GDP) } \\
\hline External debt outstanding & 9.8 & 8.8 & 7.8 & 9.9 & 8.3 \\
\hline Multilateral debt & 4.9 & 4.9 & 4.7 & 4.5 & 4.0 \\
\hline \multicolumn{6}{|c|}{ (In percent of exports and travel receipts) } \\
\hline \multicolumn{6}{|l|}{ Memorandum items: } \\
\hline Total debt service & 5.2 & 4.3 & 3.7 & 4.9 & 3.8 \\
\hline Debt service to multilaterals & 1.4 & 2.1 & 1.6 & 1.6 & 1.4 \\
\hline
\end{tabular}

Source: Central Bank of The Bahamas. 
Table 26. The Bahamas: Comparative Real Exchange Rates

(In percent)

\begin{tabular}{|c|c|c|c|c|c|c|c|}
\hline & \multicolumn{4}{|c|}{ Real Effective Exchange Rates 1/ } & \multicolumn{3}{|c|}{ Change in the period $2 /$} \\
\hline & 1990 & 1995 & 1997 & 1998 & $1998 / 90$ & $1998 / 95$ & $1998 / 97$ \\
\hline \multicolumn{8}{|l|}{ With all trading partners } \\
\hline The Bahamas & 100.00 & 100.45 & 103.15 & 105.11 & 5.11 & 4.64 & 1.90 \\
\hline Barbados & 100.00 & 101.91 & 110.75 & 108.54 & 8.54 & 6.51 & -1.99 \\
\hline Dominican Republic & 100.00 & 112.93 & 121.01 & 121.39 & 21.39 & 7.49 & 0.32 \\
\hline Jamaica & 100.00 & 91.42 & 125.69 & 132.97 & 32.97 & 45.45 & 5.79 \\
\hline Mexico & 100.00 & 81.94 & 109.12 & 111.11 & 11.11 & 35.60 & 1.82 \\
\hline \multicolumn{8}{|l|}{ With the United States } \\
\hline The Bahamas & 100.00 & 103.27 & 99.87 & 99.68 & -0.32 & -3.48 & -0.19 \\
\hline Barbados & 100.00 & 100.29 & 104.29 & 101.40 & 1.40 & 1.10 & -2.77 \\
\hline Dominican Republic & 100.00 & 110.98 & 112.37 & 109.94 & 9.94 & -0.94 & -2.17 \\
\hline Jamaica & 100.00 & 92.76 & 120.33 & 124.81 & 24.81 & 34.56 & 3.73 \\
\hline Mexico & 100.00 & 85.10 & 105.12 & 104.59 & 4.59 & 22.91 & -0.50 \\
\hline \multicolumn{8}{|l|}{ With Caribbean competitors } \\
\hline Bahamas with Barbados & 100.00 & 102.97 & 95.76 & 98.31 & -1.69 & -4.53 & 2.66 \\
\hline Bahamas with Dominican Republic & 100.00 & 93.05 & 88.87 & 90.67 & -9.33 & -2.56 & 2.02 \\
\hline Bahamas with Jamaica & 100.00 & 111.33 & 82.99 & 79.86 & -20.14 & -28.27 & -3.78 \\
\hline Bahamas with Mexico & 100.00 & 121.36 & 95.00 & 95.30 & -4.70 & -21.47 & 0.31 \\
\hline
\end{tabular}

Source: International Monetary Fund.

1/ An increase indicates appreciation.

2/ A positive number indicates real appreciation; a negative number indicates real depreciation. 